\title{
LESSONS FOR AN AGING SOCIETY: THE POLITICAL SUSTAINABILITY OF SOCIAL SECURITY SYSTEMS
}

\author{
Vincenzo Galasso* \\ Paola Profeta \\ CRR WP 2004-07 \\ Released: March 2004 \\ Draft Submitted: February 2004 \\ Center for Retirement Research at Boston College \\ 550 Fulton Hall \\ 140 Commonwealth Ave. \\ Chestnut Hill, MA 02467 \\ Tel: 617-552-1762 Fax: 617-552-1750 \\ http://www.bc.edu/crr
}

* Vincenzo Galasso is an associate professor of economics at the Università L.Bocconi. Paola Profeta is an assistant professor of public economics at the Università di Pavia. The research reported herein was performed pursuant to a grant from the U.S. Social Security Administration (SSA) to the Center for Retirement Research at Boston College (CRR). This grant was awarded through the CRR's Steven H. Sandell Grant Program for Junior Scholars in Retirement Research. The opinions and conclusions are solely those of the authors and should not be construed as representing the opinions or policy of the SSA or any agency of the Federal Government or of the CRR. The authors would like to thank Andrea Asoni for providing excellent research assistance.

(C) 2004, by Vincenzo Galasso and Paola Profeta. All rights reserved. Short sections of text, not to exceed two paragraphs, may be quoted without explicit permission provided that full credit, including $\odot$ notice, is given to the source. 


\title{
About the Sandell Grant Program
}

This paper received funding from the Steven H. Sandell Grant Program for Junior Scholars in Retirement Research. Established in 1999, the Sandell program's purpose was to promote research on retirement issues by junior scholars in a wide variety of disciplines, including actuarial science, demography, economics, finance, gerontology, political science, psychology, public administration, public policy, sociology, social work, and statistics. The program was funded through a grant from the Social Security Administration (SSA). Each grant awarded was up to $\$ 25,000$. In addition to submitting a paper, successful applicants also present their results to SSA in Washington, DC.

\section{About the Center for Retirement Research}

The Center for Retirement Research at Boston College, part of a consortium that includes a parallel centers at the University of Michigan and the National Bureau of Economic Research, was established in 1998 through a grant from the Social Security Administration. The goals of the Center are to promote research on retirement issues, to transmit new findings to the policy community and the public, to help train new scholars, and to broaden access to valuable data sources. Through these initiatives, the Center hopes to forge a strong link between the academic and policy communities around an issue of critical importance to the nation's future.

\author{
Center for Retirement Research at Boston College \\ 550 Fulton Hall \\ 140 Commonwealth Ave. \\ Chestnut Hill, MA 02467 \\ phone: 617-552-1762 fax: 617-552-1750 \\ e-mail: crr@bc.edu \\ http://www.bc.edu/crr
}

Affiliated Institutions:

American Enterprise Institute

The Brookings Institution

Massachusetts Institute of Technology

Syracuse University

Urban Institute 


\section{Introduction}

In the OECD countries, unfunded social security systems are receiving an enormous attention by both economists and policymakers. The current debate has focused on the demographic dynamics and its repercussion on the system's financial soundness. The aging process has a direct impact on the PAYG social security systems, as it tends to increase the proportion of retirees while reducing the proportion of workers. Since more people draw from a system which fewer individuals contribute to, our aging society will not be able to honor its commitment to pay social security benefits to the future retirees, unless an even larger financial burden is placed on the working generations. This simple observation has led to the conclusion that current PAYG systems will soon become financially unsustainable, since the amount of revenue will not be sufficient to cover the pension benefits awarded under the current rules.

Unless productivity increases fast enough to compensate for the negative demographics, the burden of aging will have to be sustained by some generations, through either higher contribution taxes or lower pension benefits. The political process will hence have to reconcile the opposite interests of these subsequent generations. In fact, as argued by Cremer and Pestieau (2000), the effect of aging on the PAYG social security system, and its possible reforms, depends on political factors. As the Italian Welfare Minister, Roberto Maroni, eloquently put it, when commenting on some rumors about a possible pension reform that had circulated in the government: "Before getting into the details of a proposal that will affect millions of citizens, many of which voted us in the last elections and which cannot be hit by this proposal, we should be more careful in assessing its political and technical consequences"1.

\subsection{Key issue: Political Sustainability}

In this paper, we investigate the future of social security systems in OECD countries. Since in our view the answer belongs to the realm of politics, we evaluate how political constraints shape the social security system in six countries - France, Germany, Italy, Spain, the UK and the US - under population aging.

\footnotetext{
${ }^{1}$ From the August $8^{\text {th }} 2001$ Corriere della Sera.
} 
The aim of this paper is to provide a quantitative assessment of the magnitude of the change in the size of the current social security system in our six countries that is needed to retain its political sustainability under the aging process. With political sustainability of a social security regime or reform, we mean the existence of political majority that is willing to support this pension system in all its provisions - such as retirement age, contribution method and tax rate.

The starting point of our analysis is to consider the social security system as a potentially redistributive - saving device, and to identify two main aspects of the aging process: an economic and a political effect. The economic effect of aging is given by the increase in the ratio of retirees to workers - the dependency ratio. Since the average long run return of a PAYG social security system depends on the dependency ratio and on the productivity growth, the aging process reduces the average profitability of the system. As in a portfolio decision, agents are induced to substitute their claims towards future pensions with more private savings and the size of the system should be reduced. Aging has also a direct political impact, as an older electorate increases the relevance of pension spending on the agenda of the policy-makers, and hence leads to larger and more generous systems. The latter effect is sizeable in all countries. A synthetic measure of the aging of the electorate the median age among voters - is expected to increase by at least six years in the US (from 47 to 53 years old) up to a maximum of thirteen years in Italy (from 44 to 57 years old).

\subsection{Our Findings}

- Our simulations suggest that the political effect - the increased political influence of the elderly voters - dominates, and the size of the social security system - although not necessarily its generosity - increases in all countries, albeit with some differences. Spain, the fastest aging country, faces the largest increase in the social security contribution rate.

- When labor market considerations, such as distortions from taxation, are introduced, the political effect still dominates, but becomes less sizeable. In this environment, the aging process and a rise in the retirement age increase the employment rate of the elderly workers, while reducing the labor force participation of the young 
- Country specific characteristics - not accounted for in our simulations - may matter. In countries with Beveridgean systems - the UK and the US - the aging process is likely to induce an increase in the size of the system, as well as a shift towards a less redistributive (more Bismarckian) scheme. In countries with high family ties, such as Italy and Spain, where non-emancipated adult children tend to live with their parents, the effect of aging on social security may be magnified and possible pension reforms have to be accompanied by other welfare state reform measures.

- Our simulations deliver a strong policy implication: an increase in the effective retirement age always decreases the size of the system chosen by the voters, while often increasing its generosity.

- Finally, we argue that delegation of pension policy to non-elected bodies, such as the European Commission, may facilitate the introduction of pension reform measures by decreasing the degree of political accountability of the national government.

\subsection{Organization of the paper}

To appreciate the impact of aging on the financial and political sustainability of the social security system in our six countries, in Section 2 we summarize the relevant features of the demographic process and provide a brief description of each social security system. Section 2 also surveys the recent reform measures and presents the official social security expenditure as calculated by each country. Section 3 introduces the notion of political sustainability and briefly describes the individual voting behavior. In Section 4, we analyze the relative magnitude of the two opposing effects of aging and present our sets of simulations results. Section 5 provides some discussion of some country-specific features, which may affect our simulation results. Finally, Section 6 presents our policy implications in terms of an increase in the effective retirement age and of a possible shift of the political burden of the reforms onto the European Commission. Appendix A provides technical details of the politico-economic model, while Appendix B describes the data sources.

\section{Aging and Social Security Systems}

In this section, we set up the stage to analyze the effects of aging on the political sustainability of current social security systems, by discussing the nature of the aging 
process and its strong connections with some crucial elements of the unfunded social security systems. We first present some data on the demographic projections for the next fifty years. We then summarize the main features of the current social security systems in the six countries of our sample (France, Germany, Italy, Spain, the UK and the US) and the implemented or planned reforms. Finally, we discuss the official projections on the future evolution of size of the social security system, under the forecasted demographic process.

\subsection{Demographics Elements}

The current aging process is due to the combination of an increase in life expectancy and a decrease in fertility rates. Both elements have been common to all countries in our sample. Moreover, while fertility rates are believed to recover - at least partially - their post-war levels, table 1 shows that all countries expect to enjoy a further increase of life expectancy at birth, passing for the average of OECD countries from 74.1 for male and 80.6 for female in 2000 to 79.3 for male and 84.7 for female in 2050 .

Table 1. Life expectancy at birth

\begin{tabular}{|l|c|c|c|c|}
\hline \multicolumn{2}{|c|}{2000} & 2050 \\
\hline Country & Male & Female & Male & Female \\
\hline France & 74.8 & 82.8 & 80 & 87 \\
\hline Germany & 74.7 & 80.8 & 80 & 85 \\
\hline Italy & 75.5 & 82.0 & 81 & 86 \\
\hline Spain & 74.9 & 82.1 & 79 & 85 \\
\hline UK & 75.2 & 80.0 & 80 & 85 \\
\hline US & 73.9 & 79.6 & 79.1 & 83.5 \\
\hline OECD Average* & 74.1 & 80.6 & 79.3 & 84.7 \\
\hline * Average of main OECD Countries \\
\hline Source: OECD and EC (2000) \\
\hline
\end{tabular}

These two elements will induce a substantial increase of the share of elderly people. Figure 1 shows that the proportion of elderly individuals, i.e., those older than 65 years, over the total population will rapidly increase until 2035; after that date it will remain almost constant or increase at a lower rate. This aging process will be especially accentuated for Italy and Spain, while it will be less dramatic in the UK and the US.

A measure of the aging process is provided by the old age dependency ratio defined as the ratio of persons aged 65 or more to the persons aged 20 to 64 . According to 
OECD projections, the average old age dependency ratio in the OECD countries will increase from 23.8 in the year 2000 to 49.9 in 2050. This demographic process does, however, differ across countries. For instance, as shown in table 2, the six countries analyzed belong to three different groups: Spain and Italy experience the largest growth of the dependency ratio, France and Germany are close to the OECD average, while the UK and the US are well below average.

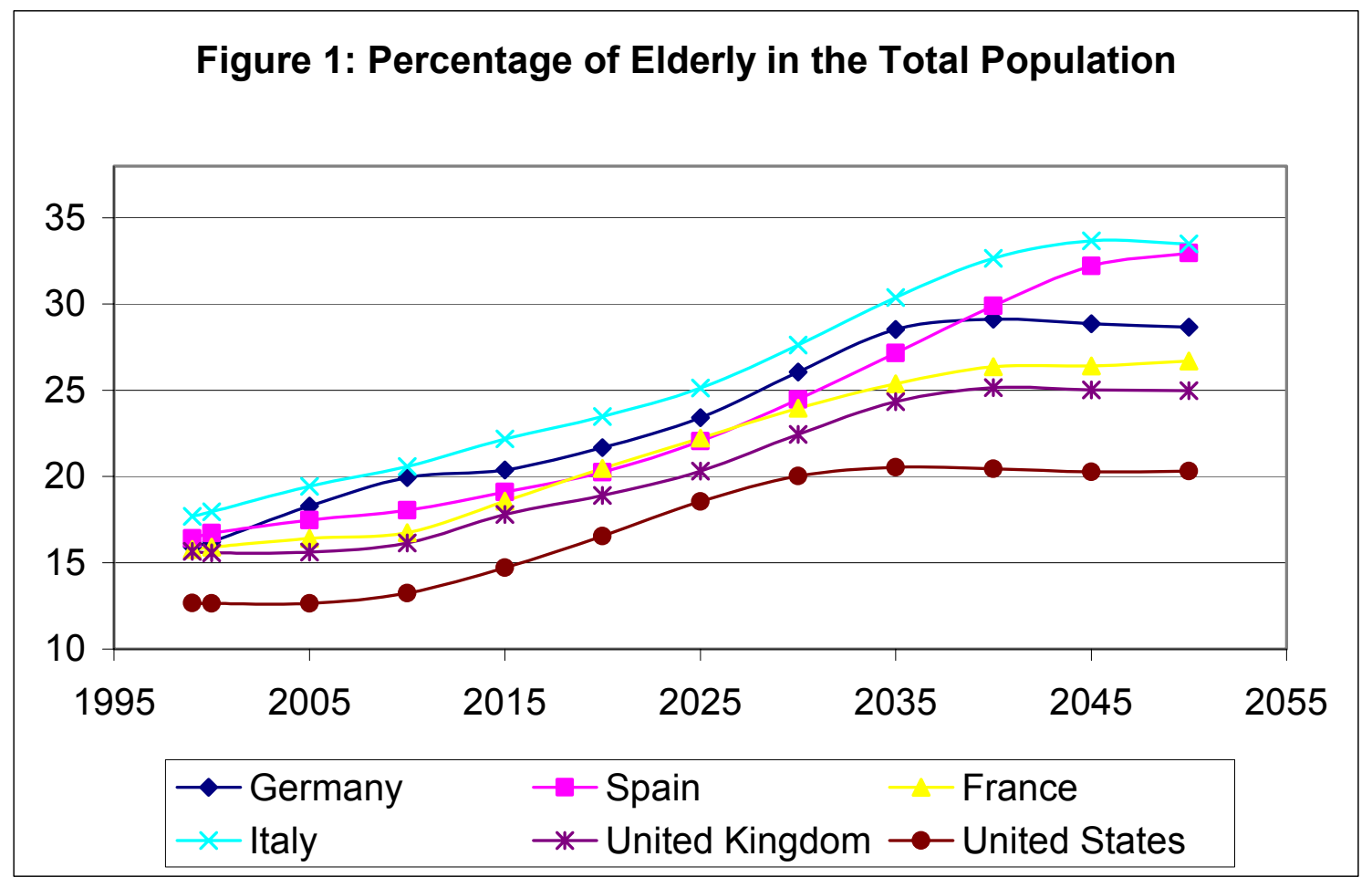

Table 2: Old-age Dependency Ratios

\begin{tabular}{|l|c|c|}
\hline \multicolumn{1}{|c|}{ Country } & 2000 & 2050 \\
\hline France & 27.2 & 50.8 \\
\hline Germany & 26.6 & 53.2 \\
\hline Italy & 28.8 & 66.8 \\
\hline Spain & 27.1 & 65.7 \\
\hline UK & 26.6 & 45.3 \\
\hline US & 21.7 & 37.9 \\
\hline OECD Average* & 23.8 & 49.9 \\
\hline \multicolumn{2}{|l|}{ *Average of main OECD countries } \\
\hline $\begin{array}{l}\text { Source: Eurostat, US Census and EC } \\
\text { (2000) }\end{array}$
\end{tabular}


The old age dependency ratio, however, does not correspond to the ratio of retirees to workers, due to the existence of early retirement provisions. Retirement policies are a crucial element to determine the structure of the labor market and the design of the pension systems. In the majority of countries around the world, there exists a legal retirement age at which the elderly are induced or required to exit the labor market before they can collect their pensions (see Social Security Throughout the World). However, this official retirement age does not correspond to the effective retirement age, due to the existence of early retirement schemes. Interestingly, the data suggest that this early retirement phenomenon has been timely related to the aging of population, that is, the labor force participation of the elderly has decreased over time, as population has aged (Costa, 1998). As a consequence, this labor market trend - extensively studied by Gruber and Wise (1999) and Brondal and Scarpetta (1998) - exacerbates the aging process, as the proportion of retirees per workers becomes even higher than the old-age dependency ratio, and thus raises an additional element of concern $v i s-\grave{a}-v i s$ the fiscal sustainability of the social security systems. According to Latulippe (1996), in 1990 the average effective retirement age for males in OECD countries was 62.2 years, down from 68.5 years in 1950. In 2000, of our six countries, only the UK (63) and the US (63) have an effective retirement age ${ }^{2}$ above the OECD average. France, Italy, Germany and Spain, on the other hand, enjoy an effective retirement age of respectively $61,58,61$ and 62 years.

\subsection{Main Features of Social Security Systems}

Table 3 summarizes the main features of the current social security systems of our six countries. All these countries have an extended PAYG social security system. In four of them - France, Germany, Italy and Spain - a funded pension scheme (second pillar) is present in an embryonic form. In the UK and the US, this second pillar is instead well developed. In the UK, for instance, employees may choose to opt out - albeit partially - of the PAYG system to join a funded scheme.

Aside from some underlying common elements, countries differ in several features, such as tax rate, benefit formula, benefit indexation, eligibility requirements and official retirement age.

\footnotetext{
${ }^{2}$ See appendix B for a description of the data source.
} 
Table 3. Principal features of PAYG social security systems

\begin{tabular}{|c|c|c|c|c|c|}
\hline Country & Tax rate & Benefit formula & $\begin{array}{l}\text { Benefit } \\
\text { indexation }\end{array}$ & $\begin{array}{l}\text { Eligibility } \\
\text { requirements }\end{array}$ & $\begin{array}{l}\text { Official retirement } \\
\text { age }\end{array}$ \\
\hline France & $\begin{array}{l}\text { Principal system: } 14,75 \% \text { ( } 8,2 \% \text { by the employers } \\
\text { and } 6,55 \% \text { by the employees) below the Social } \\
\text { Security ceiling }+1,6 \% \text { on the entire salary (due } \\
\text { by the employers) } \\
\text { Complementary system: } \\
\text { ARRCO: } 6 \% \text { ( } 1,5 \% \text { for financial balance) } \\
\text { below a ceiling for managers and professional } \\
\text { staffs, below } 3 \text { times the ceiling for other } \\
\text { employees }(60 \% \text { by the employers and } 40 \% \text { by } \\
\text { the employees). Above the Social Security ceiling } \\
\text { (or } 3 \text { times the ceiling): between } 15 \text { and } 20 \% \\
\text { depending on the firm longevity. } \\
\text { AGIRC: } 16 \% \text { ( } 4 \% \text { for financial balance) } \\
\text { applied on income between the ceiling and } 4 \text { or } 8 \\
\text { times the ceiling. }\end{array}$ & $\begin{array}{l}\mathrm{T} \times \mathrm{N} / 150 \mathrm{x} \text { Reference salary } \\
\mathrm{T}=\text { replacement rate. Based on the age of the } \\
\text { insured person and the number of years of } \\
\text { contribution. Maximum } 50 \% \text {. } \\
\mathrm{N}=\text { number of contribution quarters taken into } \\
\text { account in the scheme retained for the } \\
\text { calculation of pension. Maximum } 150 \\
\text { Reference salary = Annual average salary } \\
\text { below the ceiling. Average salary on the basis } \\
\text { of the } 19 \text { best years (to become } 25 \text { in } 2008 \text { ). } \\
\text { Complementary pension (AGIRC \& ARRCO). } \\
\text { The old-age benefit is determined by the } \\
\text { accumulation of points during the working life }\end{array}$ & $\begin{array}{l}\text { Consumer } \\
\text { price index }\end{array}$ & $\begin{array}{l}\text { Eligibility depends on the } \\
\text { payment of contribution } \\
\text { enabling the validation of } \\
\text { at least one quarter's } \\
\text { insurance. (acquired when } \\
\text { the remuneration equals } \\
\text { the amount of } 200 \text { hours } \\
\text { of the minimum wage). }\end{array}$ & $\begin{array}{l}\text { Principal system: } 60 \\
\text { years old. } \\
\text { Early retirement } \\
\text { programs: ASFNE and } \\
\text { ARPE. } \\
\text { ARRCO \& AGIRC: } \\
65 \text { years old. } \\
\text { Early retirement: } 55 \\
\text { years old. Without } \\
\text { penalizations if the } \\
\text { conditions to retire with } \\
\text { the maximum pension in } \\
\text { the principal system are } \\
\text { satisfied. }\end{array}$ \\
\hline Spain & $\begin{array}{l}4.7 \% \text { of covered earnings (insured person) }+ \\
23.6 \% \text { of earnings (employer) based on wage } \\
\text { classes that vary according to } 11 \text { occupational } \\
\text { classes. } \\
\text { Annual subsidy from the government. }\end{array}$ & $\begin{array}{l}\text { Reference salary= sum of pensionable wages } \\
\text { during the } 180 \text { months preceding retirement } \\
\text { divided by } 210 \text {. } \\
\text { Pension: } 50 \% \text { of benefit for the first } 15 \text { years of } \\
\text { contributions }+3 \% \text { for each year between } 16 \\
\text { and } 25 \text {, and } 2 \% \text { for each year beginning with } \\
\text { the } 26^{\text {th }} \text {, up to } 100 \% \text {. Since } 2002 \text {, this amount } \\
\text { may exceed } 100 \% \text { for those who retire at } 66 \text { or } \\
\text { later with at least } 35 \text { years of contributions. }\end{array}$ & $\begin{array}{l}\text { Consumer } \\
\text { price index } \\
\text { (automatic } \\
\text { adjustment) }\end{array}$ & $\begin{array}{l}15 \text { years of contributions } \\
\text { (at least } 2 \text { years during the } \\
15 \text { years immediately } \\
\text { preceding retirement). } 35 \\
\text { years of contributions for } \\
\text { a full rate retirement } \\
\text { pension. }\end{array}$ & $\begin{array}{l}65 \text { years old. } \\
\text { Transitory measure: } \\
\text { persons insured } \\
\text { according to the system } \\
\text { abolished on } 1967 \text { may } \\
\text { retire at } 60 . \\
\text { Special reduction of age } \\
\text { for groups with } \\
\text { particular professional } \\
\text { activity. } \\
\end{array}$ \\
\hline Germany & $\begin{array}{l}\text { Payroll tax equally levied on employers and on } \\
\text { employees ( } 19,5 \% \text { in 1999). Contributions are } \\
\text { calculated from the portion of salary below a } \\
\text { certain ceiling. }\end{array}$ & $\begin{array}{l}\text { PEP x C x AR } \\
\text { PEP: Personal Earnings Point. Based on the } \\
\text { level of income on which contributions were } \\
\text { paid and the allowance credited for certain non } \\
\text { contributory periods (times accession factor). } \\
\text { C: pension type factor (according to the } \\
\text { respective insurance objectives). For old age } \\
\text { pension C }=1 \text {, disability pension C }=0,6667 \text {. } \\
\text { AR: current pension value, i.e. monthly } \\
\text { pension paid to an average earner for each year }\end{array}$ & $\begin{array}{l}\text { Gross wage } \\
\text { growth }\end{array}$ & $\begin{array}{l}\text { Minimum } 5 \text { years of } \\
\text { contributions }\end{array}$ & $\begin{array}{l}65 \text { years old. } \\
\text { Early retirement: } 63 \\
\text { years old ( } 60 \text { for } \\
\text { severely handicapped) } \\
\text { after } 35 \text { years of service. } \\
\text { Women: } 60 \text { with } 180 \\
\text { contribution months. }\end{array}$ \\
\hline
\end{tabular}




\begin{tabular}{|c|c|c|c|c|c|}
\hline Country & Tax rate & Benefit formula & $\begin{array}{l}\text { Benefit } \\
\text { indexation }\end{array}$ & $\begin{array}{l}\text { Eligibility } \\
\text { requirements }\end{array}$ & $\begin{array}{l}\text { Official retirement } \\
\text { age }\end{array}$ \\
\hline Italy & $\begin{array}{l}8.89 \% \text { of earnings (insured person) }+23.81 \% \text { of } \\
\text { payroll (employer). } \\
\text { Special contributions in certain industries and tax } \\
\text { relief in economically distressed areas. }\end{array}$ & $\begin{array}{l}\text { Persons whose insurance period started after } \\
\text { January } 1,1996: \text { benefit entitlement is } \\
\text { calculated from } 33 \% \text { ( } 20 \% \text { for the self- } \\
\text { employed) of taxable base income, reevaluated } \\
\text { on an annual basis, multiplied by a convertion } \\
\text { coefficient. } \\
\text { For persons with more than } 18 \text { years of } \\
\text { contributions at December } 31,1995: \text { benefit is } \\
\text { based on a progressive percentage }(0.9 \% \text { to } \\
2 \%) \text { of salary times the number of years of } \\
\text { contributions. } \\
\text { All others: pro-quota combination of the two } \\
\text { schemes. }\end{array}$ & $\begin{array}{l}\text { Consumer } \\
\text { price index }\end{array}$ & $\begin{array}{l}\text { Old-age pension: New } \\
\text { entrants at 1996: } 57 \text { years } \\
\text { old and } 5 \text { years of } \\
\text { contributions. } \\
\text { Persons with less than } 18 \\
\text { years of contributions at } \\
1995: 65 \text { years old (men) } \\
\text { or } 60 \text { (woman) and } 20 \\
\text { years of contributions } \\
\text { prior to } 2001 . \\
\text { Persons with more than } \\
18 \text { years of contributions } \\
\text { at } 1995: 65 \text { years old } \\
\text { (men)/ } 60 \text { (woman) and } \\
15 \text { years of contributions } \\
\text { prior to } 1992 . \\
\text { Seniority pensions: } 57 \\
\text { years old and } 35 \text { years of } \\
\text { contributions or } 37 \text { years } \\
\text { of contributions, } \\
\text { regardless of the age } \\
\text { (increase to } 40 \text { by } 2008 \text { ). }\end{array}$ & $\begin{array}{l}\text { New system: } 57-65 \\
\text { years old. The amount } \\
\text { of the benefit decreases } \\
\text { if retirement age } \\
\text { decreases. }\end{array}$ \\
\hline $\begin{array}{l}\text { United } \\
\text { Kingdom }\end{array}$ & $\begin{array}{l}10 \% \text { of income between the Lower Earning Limit } \\
\text { (LEL) and the Upper Earnings Limit. The rights to } \\
\text { benefit are actually earned once earnings exceed } \\
\text { the Lower Earnings Limit. } \\
8,4 \% \text { of income between the LEL and the UEL if } \\
\text { the worker pots for a private occupational } \\
\text { schemes. }\end{array}$ & $\begin{array}{l}\text { BSP (basic state pension): flat rate pension, } \\
\text { depending only on the contributory years. To } \\
\text { achieve the maximum level of BSP the worker } \\
\text { needs a period of contribution equal to the } 90 \% \\
\text { of his working life. } \\
\text { SERPS (additional unfunded scheme): based } \\
\text { on the level of earnings; accrual rate of } 1,25 \% \\
\text { a year, based on the average indexed surplus } \\
\text { earnings (after } 1978 \text { ) between the lower and } \\
\text { upper earnings limit. For a person attaining } \\
\text { pensionable age from } 04 / 2000 \text { accrual rate } \\
\text { reduces over } 10 \text { years transitional period to } 1 \% \text {. }\end{array}$ & $\begin{array}{l}\text { Consumer } \\
\text { prices } \\
\text { legislated } \\
\text { annually }\end{array}$ & $\begin{array}{l}\text { BSP: } 11-12 \text { years of } \\
\text { contributions. } \\
\text { SERPS: earnings above } \\
\text { the lower earning limit } \\
\text { (LEL), for at least one } \\
\text { year since April } 1978 .\end{array}$ & $\begin{array}{l}65 \text { years old for men } \\
\text { and } 60 \text { for women (for } \\
\text { women it will be raised } \\
\text { between } 2010 \text { and } 2020 \\
\text { until } 65 \text { ). No early } \\
\text { retirement. Pension } \\
\text { increases of } 7,5 \% \text { yearly } \\
\text { if pension age is } \\
\text { deferred for } 5 \text { years. }\end{array}$ \\
\hline $\begin{array}{l}\text { United } \\
\text { States }\end{array}$ & $\begin{array}{l}\text { Flat tax of } 12.4 \text { percent of wage income up to a } \\
\text { ceiling equally shared by employee and employer } \\
\text { (OASI+HI+DI). }\end{array}$ & $\begin{array}{l}\text { Retirement benefits are based on average } \\
\text { earnings during a } 35 \text { year career. }\end{array}$ & $\begin{array}{l}\text { Consumer } \\
\text { price index }\end{array}$ & $\begin{array}{l}10 \text { years of contributions } \\
\text { and minimum retirement } \\
\text { age. }\end{array}$ & $\begin{array}{l}65 \text { for full benefit. } \\
62 \text { with reduced benefit. } \\
\text { From } 65 \text { to } 70 \text { benefits } \\
\text { increase. }\end{array}$ \\
\hline
\end{tabular}




\subsubsection{Social Security Contribution Rates}

The highest social security contribution rates are in Italy $-32.7 \%$ of earnings $(8.89 \%$ paid by the insured person and $23.81 \%$ by the employers) - and Spain - $28.3 \%$ (4.7\% paid by the insured person and $23.6 \%$ by the employer). Germany and France feature a salary ceiling on the contribution tax to be paid. The tax rates are 19.5\% in Germany (equally levied on employers and employees) and 14.75\% (principal system, of which $8.22 \%$ paid by the employers and $6.55 \%$ by the employees) plus $6.5 \%$ (ARRCO) in France ${ }^{3}$. Finally, the US and the UK enjoy the lowest tax rates. In the US, the tax rate is $12.4 \%$ of the income below a ceiling (equally levied on employer and employee). In the UK, the tax rate is $10 \%$ of income between the Primary Threshold (GBP 67 per week) and the Upper Earnings Limit (GBP 535 per week) and it reduces to 8.4\% of income between the Lower Earnings Income (GBP 67 per week) and the Upper Earnings Limit if the person "opts out" of the public system.

\subsubsection{Pension Benefits, Eligibility and Retirement Age}

All countries - with the exception of Italy after the 1995 Dini reform - have defined benefit (DB) PAYG system. The pension benefit depends on the number of years of contributions and on a reference wage. However, even countries with a DB system differ in how pensions relate to this reference wage, which typically depends on the worker's past wages. To this respect, the UK and the US have "Beveridgean" systems, in which pension benefits are almost flat, that is, almost unrelated to the worker's past wages. Italy, France, Germany and Spain have instead a "Bismarckian" system, which features a tight link between wages and benefits. In this case, the benefit formula is set to guarantee a certain replacement rate, i.e., the ratio between pensions and the last wage income, regardless of the worker's lifetime wage income profile. Since contributions are typically proportional to labor earnings possibly up to a ceiling - unlike a Bismarckian system, a Beveridgean system induces a large redistribution among income groups.

To be more specific, in France, the reference wage corresponds to the annual average salary limited to the social security ceiling calculated for the 19 best years (it will

\footnotetext{
${ }^{3}$ See table 3 for more details on the second PAYG pensions in France.
} 
become 25 years by 2008). In Germany, the reference wage is the personal earnings point, which depends on the level of income on which contributions were paid multiplied by the current pension value (monthly pension paid to an average earner for each year insured). In Spain, it corresponds to the sum of the wage during the 180 months before retirement divided by 210 . The pension is $50 \%$ of this amount if the contribution period is 15 years, plus $3 \%$ for each additional year between 16 and 25 and $2 \%$ for each year from $26^{\text {th }}$ up to a maximum of $100 \%{ }^{4}$. In a pure Beveridgean system, such as in the UK, the main pension is flat, i.e., it does not depend on the reference wage, although it does depend on the number of years of contribution. The second tier of the public pension (SERPS) does instead depend on the level of earnings - although it retains an element of intragenerational redistribution. Also the US have a Beveridgean system, albeit not a pure one, since the reference wage is calculated as the average earnings during 35 years of contributions, but a redistributive formula applies to reduce the pension benefits of the high lifetime earners in favor of those of the low-wage earners.

Italy presents a different scenario. In 1995, its system was changed from a (Bismarckian) defined benefit formula, in which the reference wage was calculated as the average of earnings during the entire career multiplied by the number of years of contributions, to a defined contribution scheme. After this reform, the pension entitlement is calculated as $33 \%$ of the earnings revaluated on annual basis, multiplied by a coefficient which depends on the age of retirement. This new scheme applies entirely to the workers who joined the system after January 1996, while the old formula applies to those who had more than 18 years of contributions in December 1996.

Currently, all countries but Germany index the pension benefits to inflation. In Germany benefits are instead indexed to gross wage growth, though this adjustment was temporarily suspended in 2000 and 2001.

In all countries, in order to be eligible for a pension benefit, a person should have contributed for a minimum number of years and/or have reached a minimum retirement age. The minimum contribution period varies from one quarter in France to 20 years in Italy (5 for new entrants at 1996). It is equal to 5 years in Germany, 15 in Spain, 11-12 in the UK (for the State pension) and 10 in the US.

\footnotetext{
${ }^{4}$ From 2002, people retiring later than 66 with at least 35 years of contributions may receive more than $100 \%$.
} 
All countries feature an official retirement age at which people are allowed to exit the labor market and receive their pension benefits: 60 years in France, 65 in Germany, 5765 in Italy under the new scheme, 65 in Spain, 65 for men and 60 for women in the UK, and 65 in the US. However, several countries have early retirement provisions, which allow the worker to retire before the official age on a reduced pension benefit (France, Germany, Spain, US). New rules are introducing incentives to postpone retirement in terms of higher benefits received (Italy, US).

\subsection{Reforms}

Faced with the challenges of the aging of the population, most OECD countries have implemented - or at least began to implement - some reform of the social security system. Most of these reforms have been "parametric", to the extent that the unfunded nature of the system has not been modified. According to the OECD (2002), the recent measures adopted by OECD countries have pursued three main objectives: (i) the increase in the effective retirement age, through a reduction of the incentive to early retirement and an increase in the demand for elderly workers; (ii) the reduction of the pension benefits - in order to improve the financial sustainability of the social system - through the indexation of the pensions benefits to the prices, rather than to the wages, and through changes of the benefits formulas; and (iii) the increase of the private pension arrangements - in order to modify the current mix of public-private pensions, mainly through tax incentives to contributions to private pension and by establishing new regulations for the relevant financial institutions.

Table 4 summarizes the main recent reforms in our six countries. In the last 10

years, these reforms have mainly concerned the increase of retirement age - Germany (1992 and 1997), Italy (1992 and 1995), Spain (1999) and the UK (1986) - and the development of a private second pillar (occupation funds) and third pillar (individual funds).

The latter type of reforms has characterized virtually all countries. Complementary - albeit unfunded - pension schemes already existed in France (Arrco and Agirc), and they have been strongly regulated in 1997. In Germany, the 2001 Old Pension Act has awarded additional advantages in the tax treatment of pension funds. In Italy, the Amato Reform in 
Table 4. Recent reforms

\begin{tabular}{|c|c|}
\hline France & $\begin{array}{l}\text { 1993: Changes in benefit calculation: Base period extended from } 10 \text { to } 25 \text { years. Extension of } \\
\text { contribution period to access full pension from } 37.5 \text { years to } 40 \text { years. From wage to price indexation. } \\
\text { 1997: "Thomas Law": contribution to optional private retirement funds exempted from income } \\
\text { taxation and social security contributions (later suspended by the Jospin government). } \\
\text { 1998: Partial retirement: elderly workers may opt to reduce their working hours until reaching } \\
\text { retirement age in exchange for a partial pension. }\end{array}$ \\
\hline Germany & $\begin{array}{l}\text { 1992: Progressive increase of the retirement age up to } 65 \text { for both men and women; early retirement at } \\
62 \text { with a penalty clause. Net income indexation for benefits. } \\
\text { 1997: Restricted accrual of pension rights, not based on contributions (e.g. credits for education, } \\
\text { unemployment) } \\
\text { 1997: Pension reform law (Blum reform): Replacement rate reduced from } 70 \% \text { to } 67 \% \text { (in } 30 \text { years). } \\
\text { Higher transfers from the federal budget to the pension system, covered by higher VAT rate } \\
\text { 1999: Suspension of the pension reform law; for the years } 2000 \text { and } 2001 \text { pensions are indexed to } \\
\text { inflation rather than net wages } \\
\text { 2001: Old-Age Provision Act (still requiring the Bundesrat approval): promotion of additional funded } \\
\text { pensions trough subsidies and tax treatment; individual right of workers to an occupational pension, } \\
\text { and (Extension Act) lower adjustment of pensions (replacement ratio from } 70 \% \text { to } 64 \% \text { ) } \\
\text { 2002: Incentives for occupational and private schemes }\end{array}$ \\
\hline Italy & $\begin{array}{l}\text { 1992: Amato Reform: Introduction of occupational private schemes (with tax advantages); increase in } \\
\text { retirement age from } 55 \text { to } 60 \text { for women and } 60 \text { to } 65 \text { for men; pension benefits reference period } \\
\text { gradually to the entire working career; minimum period to get a contributive pension raised from } 15 \text { to } \\
\text { 20 years; from wages to inflation indexed pension benefits. } \\
\text { 1995: Dini Reform: flexible retirement age (from } 57 \text { to } 65 \text { for both men and women); from defined } \\
\text { benefit to defined contribution (see table } 3 \text { ); Seniority Pension: Eligibility raised to } 40 \text { years of } \\
\text { contributions (or } 35 \text { if aged } 57 \text { ); fiscal incentives for contributions paid to private pension funds } \\
\text { 1997: Prodi Agreement: Increase of the early retirement age; harmonization of public and private } \\
\text { pension regimes and increased pension contributions paid by the self-employed; temporary measures } \\
\text { to postpone access to early retirement benefits and to suspend inflation adjustment for high pensions; } \\
\text { more stringent requirement for access to seniority pensions; increase of contributions for self- } \\
\text { employed workers and other categories; increase of the amount of social and minimum pensions, tax } \\
\text { deductions for pensioners with lower income; tax incentives to convert the TFR (end-of-career } \\
\text { severance payment) into supplementary pensions } \\
\text { 2000: Tax incentives for returns of pension funds (taxed at } 11 \% \text { instead of the standard } 12.5 \% \text { tax rate } \\
\text { for returns of financial activity) and TFR (end-of-career severance payment) invested in pension } \\
\text { funds. }\end{array}$ \\
\hline Spain & $\begin{array}{l}\text { 1997: "Toledo pact": gradual extension of the basis to calculate pensions from the last } 8 \text { to the last } 15 \\
\text { years of contribution. Automatic price indexation. Reserve fund built with contribution surplus. } \\
\text { 1997: Reduction of the incentives to retire early } \\
\text { 1999: New partial retirement scheme aimed at persuading older workers to continue working. } \\
\text { 2000: Creation of a Fund for the transition to a mixed system combining PAYG and funding }\end{array}$ \\
\hline $\begin{array}{l}\text { United } \\
\text { Kingdom }\end{array}$ & $\begin{array}{l}\text { 1986: Flexible retirement age to } 70 \text {; Reduction of value of public earnings related schemes } \\
\text { (calculation basis: from } 20 \text { years to all the working life; replacement rate: from } 25 \% \text { to } 20 \% \text { ) } \\
\text { 1995: Pension Act: State pension retirement gradually increased for females from } 60 \text { to } 65 \text { years; introduction } \\
\text { of a Personal Pension and regulation of the occupational schemes } \\
\text { 1999-2002: Welfare Reform and Pension Act: introduction of Minimum Income Guarantee and of a } \\
\text { Pension Credit aimed at rewarding savings; SERPS replaced by the New State Second Pension (S2P) } \\
\text { to help lower income; introduction of the New Stakeholder pension scheme (SPSs) for middle-income } \\
\text { earners with no existing private pension provision. }\end{array}$ \\
\hline $\begin{array}{l}\text { United } \\
\text { States }\end{array}$ & No significant reforms \\
\hline
\end{tabular}

Source: EC - DG Employment and Social Affairs (2002) "Social Security in Europe -2001" and Rodolfo Debenedetti Foundation Report (2000) "Monitoring slow Pension reforms in Europe". 
1993 has introduced occupational schemes and subsequent legislative interventions in 2000 have introduced special tax treatments for non-mandatory funded pensions (their returns are taxed at $11 \%$, rather than the standard $12.5 \%$ on returns from other financial activities) and for investing part of the TFR (an end-of-career severance payment) into occupational pension plans. Despite having a well-developed second pillar, in 1995, the UK has passed a Pension Act which allows for the possibility of opting out of (part of) the state pension system and of contributing in personal pension funds.

In addition to these reform measures, there has been a common trend towards moving from wage to price indexation of pension benefits. Other, more limited, reforms have been small increases in the contributory tax rates (Germany), in the years of contributions and in the reference salary period to calculate the pension (Spain, Italy with the 1992 Amato reform). More radical measures have been introduced in Italy, with the Dini reform in 1995, which have radically changed the benefit formula from defined benefit to defined contribution. However, this reform has involved such a long transition period that most of the effects will be observed only in thirty to forty years.

\subsection{Projections}

Despite the widespread opinion that further reforms are needed - according to a recent survey conducted in Germany and Italy by Boeri, Boersch-Supan and Tabellini (2002), a large majority of the population (85\% in Germany and 63\% in Italy) expects the system to face a crisis in the next 10 to 15 years - several governments are confident that these reform measures are sufficient to obtain the long run financial sustainability of the system. The OECD has asked each member country to make projections of social security spending (as percentage of GDP) over the next fifty years and to disentangle the different effects of demographic, employment and policy factors. Table 5 shows the official projections provided by each country's government reported in OECD (2002). Italy stands out as the most striking case: in spite of having the largest demographic effect - capable of increasing the pension spending by $10 \%$ of GDP - the pension spending is expected to decrease in the year 2050, due to the projected increase in the employment rate of elderly workers and thanks to the measures introduced by the Amato-Dini reforms. Also the UK is expected to reduce its pension spending, as the policy measures counterbalance a mild 
aging effect. In all other countries, the estimates suggest an increase in the amount of resources devoted to pensions. In Spain, a strong demographic effect is even magnified by a policy that extends pension eligibility, while in Germany and France the reform measures are not strong enough to neutralize the aging process. Not surprisingly, in the US the increase in spending is below the OECD average.

Table 5: Official Projections of Old Age Pension Expenditures over GDP

\begin{tabular}{|l|c|c|c|c|c|c|}
\hline & & & \multicolumn{3}{|c|}{ Contributions to changes from 2000 to 2050, of: } \\
\cline { 4 - 7 } Country & 2000 & 2050 & $\begin{array}{c}\text { Old Age Dependency } \\
\text { Ratio }\end{array}$ & $\begin{array}{c}\text { Employment } \\
\text { Rate }\end{array}$ & $\begin{array}{c}\text { Benefit } \\
\text { Formula }\end{array}$ & Eligibility \\
\hline France & 12.1 & 15.9 & 7.6 & -0.5 & -3.4 & 0.4 \\
\hline Germany & 11.8 & 16.8 & 6.4 & -0.7 & -2.7 & 2.1 \\
\hline Italy & 14.2 & 13.9 & 10.1 & -3.2 & -5.5 & -1.5 \\
\hline Spain & 9.4 & 17.4 & 8.6 & -2.6 & 0 & 2 \\
\hline UK & 4.3 & 3.6 & 1.7 & 0.1 & -2.5 & 0.1 \\
\hline US & 4.4 & 6.2 & 2.4 & -0.1 & -0.2 & -0.3 \\
\hline \multicolumn{2}{l|}{ Source: OECD (2002) }
\end{tabular}

\section{Political Sustainability of Pension Systems}

A recent literature has put forward a line of explanation for the institution of the unfunded social security systems and their development into the most widespread instrument of social insurance, which relies on a political economics characterization (for a comprehensive review see Galasso and Profeta, 2002). The key intuition is that social security systems need not be welfare enhancing to be in place, they only need to be sustained politically. In democracies, a measure of such support would be the approval of a majority of the Parliament or, more directly, of the electorate ${ }^{5}$.

In this paper, we directly identify the preferences of the different types of voters regarding the social security system, in an environment in which agents evaluate the system as a saving device. As suggested in the theoretical literature, there are several reasons why young and middle-aged voters may choose to support a PAYG system: (i) the system may provide better returns than alternative saving instruments (Aaron, 1966), (ii) individuals may be altruistic (Hansson and Stuart, 1989), (iii) agents may only consider a reduced time horizon in evaluating the social security program (Browning, 1975), (iv) the existence of a

\footnotetext{
${ }^{5}$ Mulligan and Sala-i-Martin (1999) suggest that these systems exist also in non-democracies and hence they do not depend on voting, but on the lobbying activity by the elderly.
} 
social security system may crowd-out aggregate savings thereby achieving redistribution between capital and labor income (Cooley and Soares, 1999), and (v) the system may entail an element of within-cohort redistribution that favors the low-income individuals at the cost of high income ones (Tabellini, 2000). Here, we disregard the former two motivations and built a politico-economic model that concentrates on the latter three elements, to evaluate the relevance of the redistributive components, both within and across generations, to the different individuals.

These agents' individual preferences over the social security system can be aggregated through several political mechanisms. Here, we concentrate on majority voting. Hence, by political sustainability of a social security regime or of a reform, we mean the existence of a political majority that is willing to support this pension system in all its provisions - such as retirement age, contribution method and tax rate.

Clearly, the decision process behind any reform of a social security system is more complex than what a simple voting game may capture. However, this simple environment allows us to highlight the main aspect of the impact of the demographic dynamics on the political process, and the majoritarian voting model is the minimum institutional requirement to cast the analysis in this framework.

\subsection{The Economic Environment and the Social Security Systems}

To provide a quantitative analysis of the political sustainability of the social security systems in our six countries, we use a theoretical framework that enables us to examine the economic and political choices of the agents, in their double role of consumers and voters. This theoretical framework has to capture the economic and demographic aspects, the institutional elements related to the different social security systems and the political scenario of the different countries (See Appendix A for a formal description of the model).

For the economic modeling, we rely on a family of large overlapping generations general equilibrium models calibrated - for each country - to the main demographic and economic features. In these lifecycle economic models, every agent - depending on her expected lifetime horizon and income - decides how much to save for future consumption, with the goal of smoothing consumption over time. The economy is populated by several overlapping generations of workers and retirees. Workers supply labor during their working 


\section{BOX 1: The Calibration Exercise}

This calibration exercise pins down - for each country - the values of some key parameters of our political-economic model in order to match each country's main economic, demographic, pension system's and political characteristics.

Demographics Every period in the model corresponds to one year. Agents are born at age 18 and may live up to age 95, according to age specific probability of survival. For each country, these probabilities are averages by gender of 1999 official estimates. To simulate the aging process, we use official 2050 surviving probabilities for France and the US, while for Germany, Italy, Spain, and the UK, we calculate them by reducing by $10 \%$ the 1999 official mortality rate. For Italy and the UK, we also calculate surviving probabilities by education level according to the following procedure: official survival probabilities obtained are assigned to agents in the intermediate education group. Survival probabilities of agents in the low education group are obtained by increasing the mortality rate by $5 \%$ at every age; while the survival probabilities of the agents in the third group - the high education level - are obtained by reducing it by $5 \%$. The population growth rate used in the calibration (for 1999) and in the simulation (for 2050) is calculated to match - given the corresponding surviving probability - the elderly dependency ratios at table 2 . The figure in this box displays the 1999 actual and 2050 forecasted population pyramid, as well as the 1999 and 2050 population pyramid used in the model for France.

Labor Market In the model with exogenous labor supply (see the appendix and section 4.2), the average amount of time dedicated to productive activities equals the average employment rate. Agents differ in labor efficiency by age and education: this index, which corresponds to the labor income lifetime profile, is obtained by using country-specific microeconomic data on labor income by age. In the endogenous labor supply model (see the appendix and section 4.3), the endogenous amount of time dedicated to productive activities by age is calibrated to the average employment rate by age. The labor efficiency index by age and education is obtained on microeconomic data by combining wage income and employment rate by age.

The retirement decision is exogenous in our model. In every country's calibration, we use the overall median retirement age in 1999 as obtained from country-specific micro data. For Italy and the UK, we also consider the median retirement age and the working history according to the education level. In the 2050 simulations, the retirement age constitutes a policy instrument as discussed in section 6.1 . 


\section{France: Population Profile}

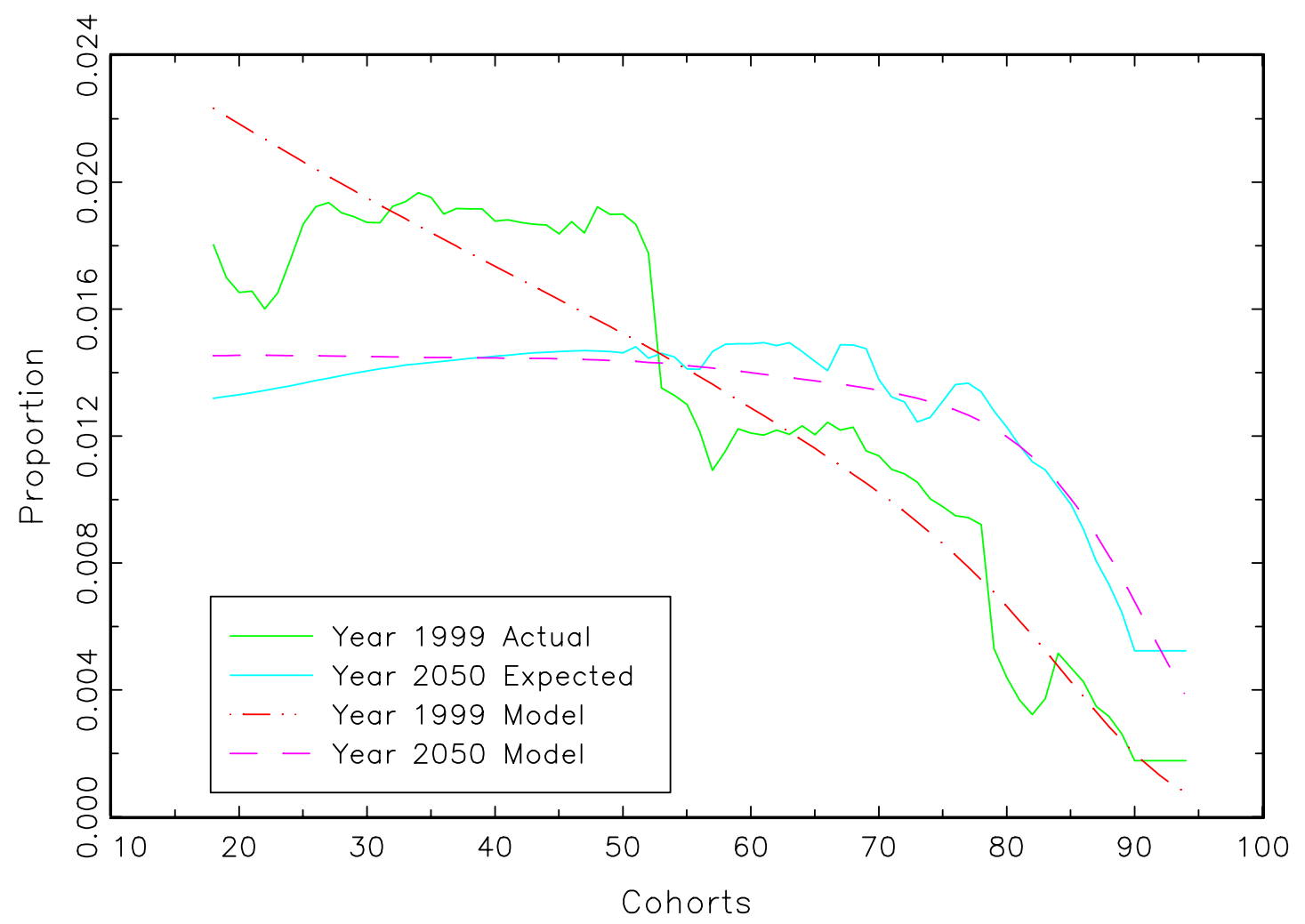

Technology and Preferences

For our constant return to scale production function, the value of the average capital share is taken by national accounts. In every country, the exogenous productivity growth is given by the average per-capita GDP growth rate in the 90s, while in the simulations we use EC projections. The long term characteristics of each economy are described by the capital-output ratio (see Cooley and Prescott, 1995). For every country, we obtain its average value from several publications (see Appendix B). Depreciation rate is taken to be equal to $5 \%$.

Pension Systems We concentrate on the equilibrium contribution tax rate, that is on the tax rate that equates the total contributions to the total pension benefits paid out at each point in time, rather than on the legal contribution rate to the system. For instance, if a country (e.g., Italy) runs a pension deficit, we impute the transfer from the general taxation to the tax rate, thereby having that the equilibrium tax rate is higher than the legal one.

Political Features As in Galasso (1999), the political-economic model is calibrated in order to have that the tax rate determined in the model by the median voter is equal - for every country - to the actual (equilibrium) tax rate that financed the pension system in 1999. If agents only differ by age, the crucial political variable to parameterize the political system is the age of the median voter 
(see table 6). However, if individuals differ also by education, as in the case of Italy and the UK (see section 5.1), because of the intragenerational redistribution elements, the median voter has to be identified in terms of age and education class. In computing the median voter, we always consider the electoral participation rate by age - and, when relevant, by education classes.

\section{Estimated Parameters of the Politico-Economic Model}

\begin{tabular}{|l|c|c|c|c|c|c|}
\hline & $\underline{\text { France }}$ & $\underline{\text { Germany }}$ & $\underline{\text { Italy }}$ & $\underline{\text { Spain }}$ & $\underline{\text { U.K. }}$ & $\underline{\text { U.S. }}$ \\
\hline Population growth & $1.04 \%$ & $0.62 \%$ & $0.7 \%$ & $0.8 \%$ & $0.5 \%$ & $1.35 \%$ \\
\hline Avg. employment rate & $65.4 \%$ & $71.4 \%$ & $45.6 \%$ & $43.5 \%$ & $64.7 \%$ & $60 \%$ \\
\hline Effective retirement age & 61 & 61 & 58 & 62 & 63 & 63 \\
\hline Capital share & $31 \%$ & $34 \%$ & $38 \%$ & $34.7 \%$ & $30 \%$ & $36 \%$ \\
\hline Capital-output ratio & 2.21 & 2.32 & 3.18 & 2.37 & 1.81 & 2.43 \\
\hline Productivity growth & $1.6 \%$ & $1.8 \%$ & $1.92 \%$ & $2.2 \%$ & $2.6 \%$ & $1.94 \%$ \\
\hline Median voter's age & 43 & 46 & 44 & 44 & 45 & 47 \\
\hline Equilibrium tax rate & $22.4 \%$ & $23.8 \%$ & $38.0 \%$ & $18.8 \%$ & $14.5 \%$ & $9.7 \%$ \\
\hline
\end{tabular}

Source: see Appendix B

Calibrated Parameters For each country, the politico-economic model is calibrated to match two basic parameters: the capital-output ratio and the equilibrium pension tax rate (as chosen by the median voter). With these restrictions we obtain, for each country, two parameters of utility function: the subjective time discount rate and the coefficient of relative risk aversion. As described above, all other parameters are obtained from independent empirical estimates.

\section{Calibrated Parameters of the Politico-Economic Model}

\begin{tabular}{|c|c|c|c|c|c|c|c|}
\hline Version & Variables & France & Germany & Italy & Spain & U.K. & U.S. \\
\hline \multirow{2}{*}{$\begin{array}{l}\text { Exogenous } \\
\text { Labor Supply }\end{array}$} & Coef. relative risk aversion & 1.9175 & 2.406 & 2.695 & 2.0365 & 3.65 & 4.175 \\
\hline & Subjective discount rate & 1.00 & 1.0145 & 1.0725 & 1.0065 & 1.0375 & 1.0842 \\
\hline \multirow{3}{*}{$\begin{array}{l}\text { Endogenous } \\
\text { Labor Supply }\end{array}$} & Coef. relative risk aversion & 2.86 & 3.185 & 2.425 & 2.71 & 4.8425 & 9.95 \\
\hline & Subjective discount rate & 1.028 & 1.042 & 1.0565 & 1.02 & 1.079 & 1.35275 \\
\hline & $\begin{array}{lll}\begin{array}{l}\text { Preference } \\
\text { consumption }\end{array} & \text { elasticity } & \text { of } \\
\end{array}$ & 0.725 & 0.825 & 0.613 & 0.6055 & 0.747 & 0.805 \\
\hline
\end{tabular}


years and then retire at an exogenous retirement age. Agents may differ within each age cohort by level of education and, accordingly, by retirement age, working history, longevity, income and degree of political participation. They also differ across cohort in working ability: in fact, not only more educated agents tend to be more productive, but, at any given time, middle aged workers are more productive than young and elderly workers. The production side of the economy is represented by a constant returns to scale aggregate production function, which transforms the productive factors - labor and capital - into the

production of a unique good. Labor productivity is assumed to grow at a constant rate due to exogenous technical progress.

The demographic aspects are summarized by the population growth rate, the age specific survival probabilities and the dependency ratios. The institutional features of the social security system are characterized by several elements, such as contribution rate, retirement age, rules for pension benefits calculation and indexation.

\subsection{Individual Voting Behavior and the Political Game}

In our political environment, every individual acts as a political agent: she votes over the size of the system - specifically over the social security contribution rate - given the different institutional settings prevailing in each system, such as retirement age, indexation rule, and so on. This choice will typically depend on her individual characteristics, such as age and educational attainment, and on the main features of the system.

To fix ideas, consider a one-time election, whose outcome is binding in all future periods (see box 2 for the extension to repeated elections). A PAYG social security system imposes a cost to the young - the contribution - and provides a transfer - the pension benefit - to the elderly. Retirees will hence always support such a system, whereas workers may be willing to incur in a current cost only if they will be sufficiently compensated by future pension benefits. More generally, every individual, in taking her voting decision over the size of the system, will consider her current and future contributions to the system and her future benefits and will evaluate the effectiveness of a social security system as a saving instrument. In particular, every voter determines the amount of resources that she would like to transfer into the future through the social security system - her most preferred size 
of the system - by comparing her overall return $^{6}$ from the system to the returns available on the capital market from assets with comparable risk.

Figure 2: Voter's Time Horizon

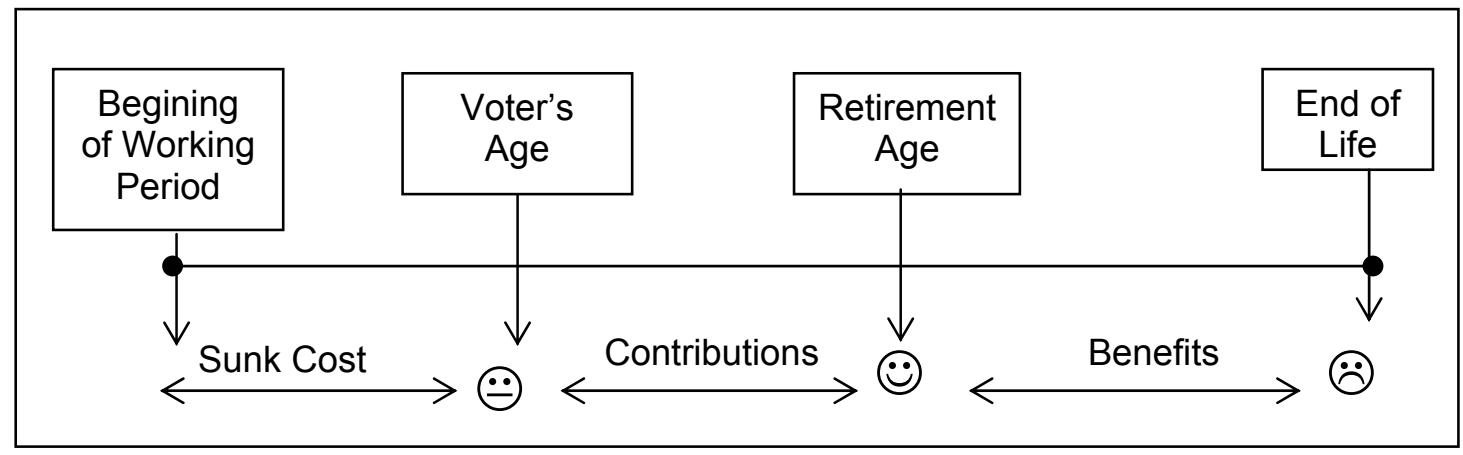

It is crucial to notice that, as initially suggested by Browning (1975), past contributions to the system do not affect the agents' voting decision, since they could not be appropriated by the voters, were the system to be abandoned, and thus represent a sunk cost. Hence, middle aged and elderly individuals are more favorable to social security systems, as they will almost exclusively enjoy benefits in their remaining time horizon. Figure 2 describes the individual's residual horizon when taking her voting decision.

These individual voting decisions are then aggregated in a simple majority voting. Hence, to the extent that preferences are single-peaked, the equilibrium outcome of the voting game coincides with the most preferred size by the median voter.

We clearly recognize that decisions over social security systems are more complex than a simple majoritarian voting model would predict. Additional political players, such as trade unions and employers unions, may exert an intensive lobbying activity on the policymakers to affect the policy outcome or elderly voters may obtain a disproportionate political influence as if they were holding a veto-power (see Azariadis and Galasso, 2002). A recent literature - see Bonoli (2000) among others - has argued that institutional features play a crucial role in shaping pension policies - in particular, the retrenchment of these systems - as they determine the existence of veto-players able to block any reform process.

\footnotetext{
${ }^{6}$ In a partial equilibrium setting, a measure of the effectiveness of social security is given by the continuation internal rate of return (CIRR), which is the discount rate that equalizes the value of the stream of current and future contributions to the value of the stream of future benefits (see Galasso, 2002, for a calculation of the CIRR from the social security system for the US median voter). In our general equilibrium environment, we also take into account the effects on wage and rate of returns driven by changes in the stock of capital.
} 


\section{BOX 2: POLITICAL SUSTAINABILITY AND REPEATED ELECTIONS}

Current social security systems have been shaped over time by a long sequence of legislative acts. For instance, the Italian pension system was initially instituted in 1919 as a funded scheme; however, in the aftermath of the second World War, the system underwent a major change by becoming PAYG. This structural change was due to the effect of the war inflation, which eroded the real value of the pension system's assets. To help the elderly to recover their savings, a PAYG was introduced that required the (young and middle-aged) workers to provide for the elderly pensions. Analogously, a social security system was established in 1934 in the US, with the "New Deal" as a response to Great Depression that wiped out the savings of the elderly. The system was initially fully funded, but it soon became PAYG as an intergenerational transfer of resources was needed to rescue the elderly from poverty. All these processes have clearly enjoyed the "political sustainability" of a Parliamentary majority.

A recent "political economics" literature has examined the relevance of these political constraints in shaping the pension policies, by using theoretical models that provide a stylized representation of these rather complex political decisions. Here we consider a model of direct democracy ${ }^{1}$. Pension policy decisions depend on the voters' individual decisions, and are aggregated by the political system at simple majority. Elections take place every period (hence every year in our setting) and previous policies may be changed at no cost.

A key element of these pension games is their dynamic nature. In a repeated elections environment, when taking her voting decision, an agent may consider that her choice will have an impact on future voters' decisions. In this case, as shown by Galasso (1999), subgame perfect equilibrium outcomes of this repeated voting game coincide with those obtained in a once-and-for-all voting. In fact, a young voter will be willing to support a specific social security regime, and thus to pay the contribution to the system, if she expects her decision to induce future workers to sustain the system when she has retired. Since

\footnotetext{
${ }^{1}$ See Galasso e Profeta (2002) for a survey of the literature on the political economics of social security.
} 
current retirees always support the system, a social security system may emerge as an intergenerational transfer from current workers to current retirees.

The (subgame perfect) equilibrium outcome of this stylized political system is to be interpreted as a self enforcing implicit contract among successive generations of agents. Sjoblom (1985), and later Cooley and Soares (1998), Galasso (1999), and Boldrin and Rustichini (2000) among others, suggested that this social norm emerges among the majority of the voters at each election. The social security system is not based on a constitutional right defined once and for all by some planner. Retirees' claims to a pension are rather the (subgame perfect) equilibrium outcome of a political game played by successive generations of voters according to the majority rule and could potentially be amended in the future.

To see why voters have an incentive to comply with this implicit contract, consider what follows. With a pension system in place, the contract requires the voters to support the current system, if it is in their self-interest. Agents may also modify the system to improve on their current condition as long as this does not lead future generations - hurt by the changes - to dismantle the system. This is because the contract also requires the voters to punish those who have previously and "inappropriately" changed the system by giving them no transfer ${ }^{2}$. With no social security in place, a majority of voters may choose to institute a system. This would lead to an implicit contract to be accepted, as argued above, by all future generations of electors.

\footnotetext{
${ }^{2}$ Notice that also future voters will have an incentive to cope with the contract. In fact, if they do not - for instance by deciding not to pay the pension benefits to the current retirees - the successive voters would give them no pension, and hence they would live in an economy with no social security. Voters have also an incentive to punish those who have inappropriately modified the system, otherwise they would be punished by future voters for these behavior. In this case, they would have sustained the cost of contributing without receiving a pension: definitely an avoidable strategy.
} 
Our modeling choice abstracts from these considerations, however it has the advantage of providing a coherent and transparent analysis of the impact of the demographic dynamics on the political process ${ }^{7}$.

\section{Aging and Political Sustainability}

Before evaluating the future political sustainability of current social security systems, given the underlying population aging process, a preliminary investigation is needed: are these systems sustainable as of today? To answer this question, we use the results of the Eurobarometer survey conduced by Eurostat as a proxy for the individuals' preferences. Figure 3 displays the reactions in a selection of EU countries to the following statement: "current pension levels should be maintained even if this means raising taxes or contributions". In an average of the fifteen EU countries, three out of four interviewed people think that current pension levels should be maintained even if this requires an increase in taxes. We take these answers as evidence that systems are currently sustainable. The defense of the current pension level is particularly strong in Spain and in the UK where respectively $81.5 \%$ and $89.6 \%$ of the population are willing to accept a tax increase in order to retain their pension benefits.

\subsection{Aging of the Electorate}

As population ages (see section 2.1), so does the electorate. This indirect effect of population aging may have important repercussion on the political sustainability of social security systems, as it leads to an increase in the political influence of the elderly voters, and hence in the relevance of pension spending on the agenda of the policy-makers.

The effect of the demographic phenomenon may even be amplified by the individual's voting behavior. In fact, to the extent that elderly voters have a higher turnout rate at elections - defined as the percentage of people who actually vote among those who have the right to - than the young, aging leads to a disproportionate increase in the political participation of the elderly. This voting pattern $^{8}$ typically arises in the US electorate -

\footnotetext{
7 Additionally, Bonoli (2000) seems to suggest that institutional features did not play a relevant role in the expansion phase of the welfare state.

${ }^{8}$ Clearly, the voting patterns are endogenous. Perhaps, elderly people participate more at elections because they have more free time (as suggested for instance by Mullingan and Sala-i-Martin, 1999) or because they
} 
Figure 3: Current Pension Levels Should be Maintained even if this Means Raising Taxes or Contributions

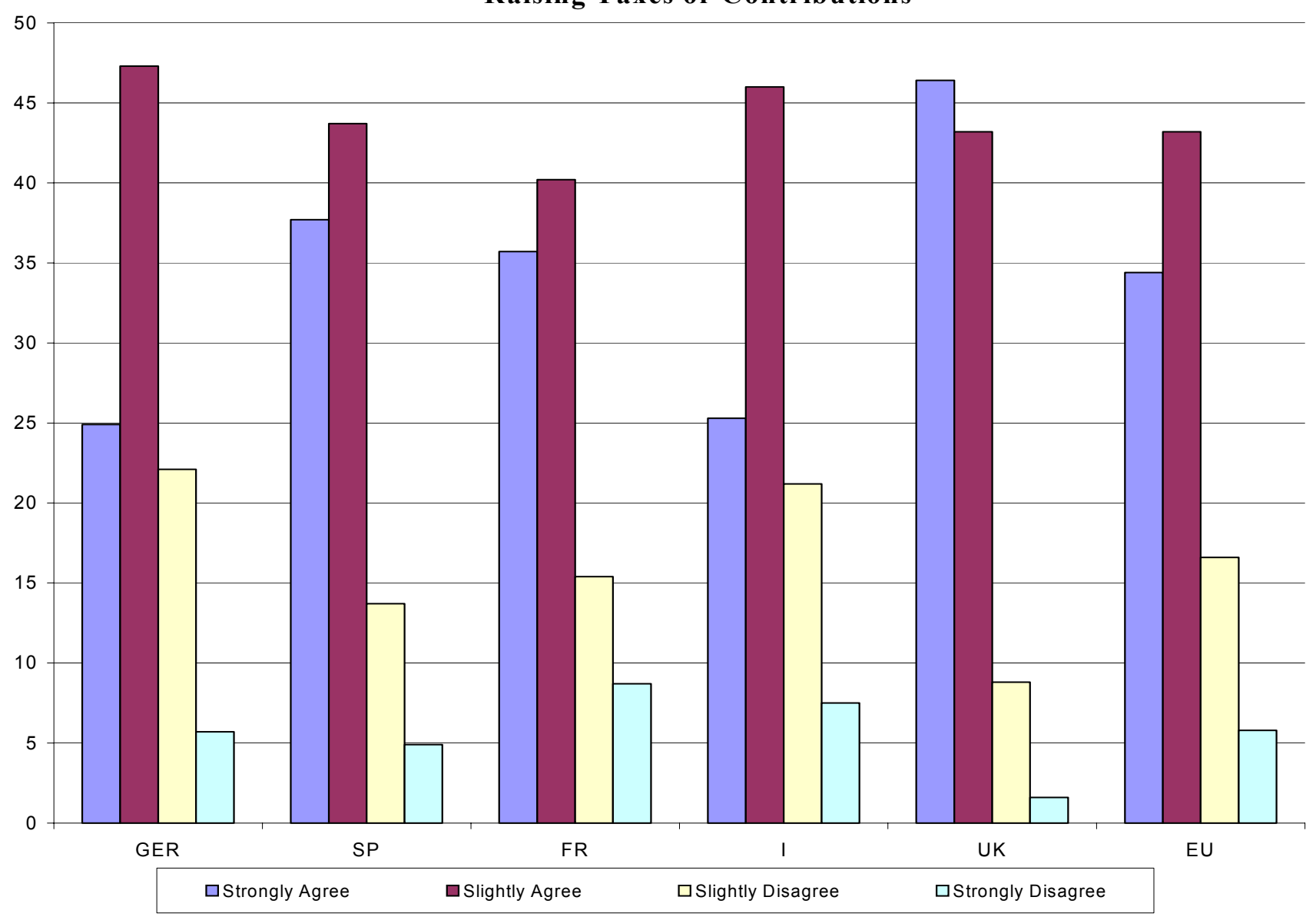

turnout rates among those aged 60 to 69 years is twice as high as among the young (18 to 29 years) - however, significant differences appear also in other countries - in France, the turnout rate of the elderly (60 to 69 years) is almost 50\% higher than that of the young (18 to 29 years).

A synthetic measure of the aging of the electors is given by the median age among the voters. In 1999, the median age among potential electors ranged between 43 years in Spain and the US and 46 in Italy. After accounting for the different turnout rates by age, the median age among the actual voters ranged between 44 years in Spain and 47 years in France and the US. The evolution over time of the median age among voters is displayed in figure 4. The expected increase is striking. In 2050, the median age will be between 53 years - in the UK and the US - and 57 years in Spain. Unsurprisingly, Spain and Italy, which undergo the most dramatic aging process, face the largest change in the median age, respectively 13 and 11 years, while in the US and in the UK, where the demographic dynamic is less extreme, the median age increases by 6 and 8 years respectively. 


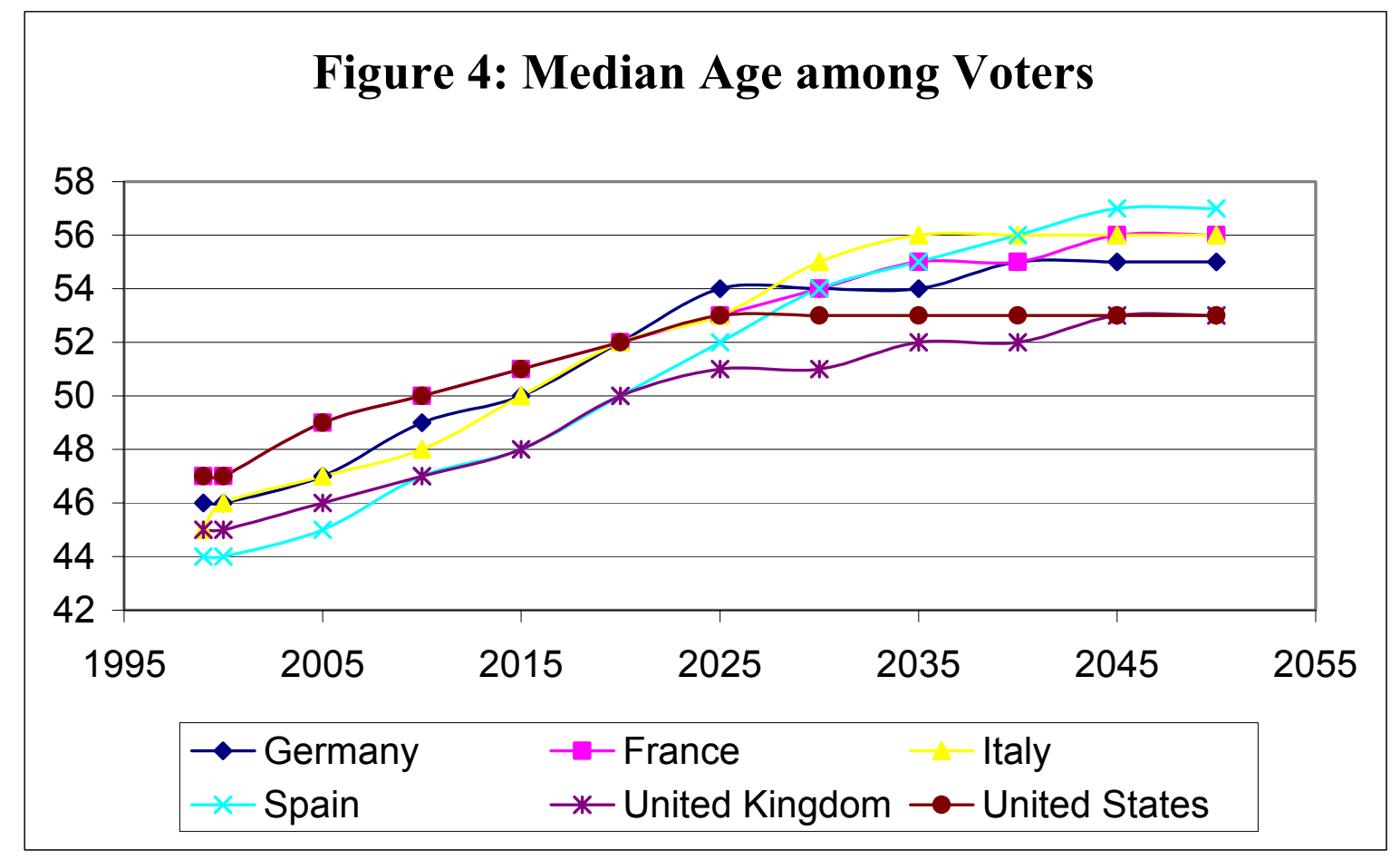

In our theoretical framework of majoritarian voting, the increased relevance of the elderly voters translates into more political power - as measured by their share of votes - to individuals who are close to retirement age, and hence who will only consider a reduced time horizon in evaluating the social security program (Browning, 1975). Figure 5 provides an interpretation of the effect of the aging of the median voter's decisions for two representative countries, Spain and the US. In the year 2000, the US median voter expected to face 18 years of residual contributions to the system and 9 years worth of pension benefits, against respectively 19 years of contribution and 12 years of benefits for the Spanish decisive voter. In this scenario, the contribution rate to the social security system was $9.7 \%$ in the US and $18.8 \%$ in Spain. In 2050, for the US median voter the remaining years of expected contributions are 12 vis-à-vis 14 years of pension benefits. For the Spanish median voter, the years of contributions are down to 8 - even assuming an increase in the retirement age from 63 to 65 years - while the benefits period is expected to increase to 14 years. According to the argument discussed in section 3.2, we should hence expect the aging of the voters to lead to a larger size of the social security system.

simulations, however, we take the turnout rate at elections as given. 


\section{Figure 5: Aging and Voting Behavior}

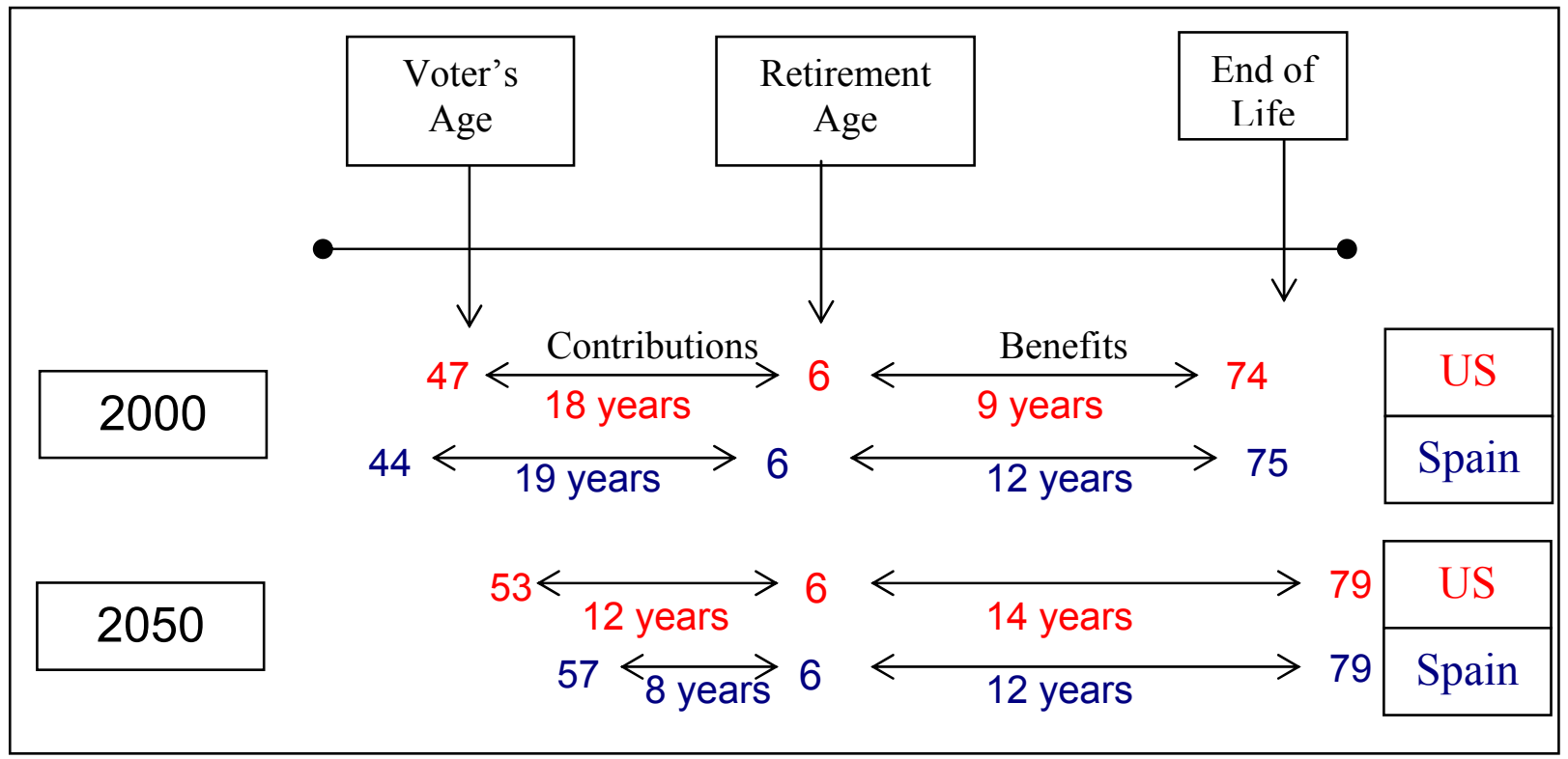

\subsection{The Direct Impact of Aging}

Demographic dynamics, labor market trends and economic conditions affect the long run performance of unfunded social security systems. Survival probabilities, population and productivity growth rates represent the relevant demographic and economic variables in the social security bill. In particular, the average long run return of a PAYG social security system is given by the sum between the population and the productivity growth rate, while the individual survival probabilities define the length of time during which pension benefits are received.

A decrease in the population growth rate, associated to an increase in the survival probability for the elderly, leads to an older population, and reduces the profitability of the system as a saving device. As the dependency ratio - the ratio of retirees to workers increases, the social security system will have to be modified, either by decreasing the retirement benefits or by increasing the financial burden on the working population, i.e., the contribution rate. Demographic dynamics also have positive effects, as an increase in the longevity extends the period of time during which pension benefits are received. 
Increases in the productivity growth rate tend to have a positive impact on the profitability of the system, by raising wages and thus total contributions to the system ${ }^{9}$. Conventional wisdom suggests that, in this case, the same pension benefits could be provided with a lower tax rate. The political channel, however, implies that, since the returns from social security have increased, savers - in their political role of voters - will have an incentive to increase the tax rate in order to transfer more resources through this improved saving instrument. This tendency may be overturned ${ }^{10}$ if pension benefits are indexed to inflation, and hence higher productivity growth leads to lower purchasing power for the pension of the very old.

Table 6: Double Effect of Aging

\begin{tabular}{|l|c|c|c|c|}
\hline Country & \multicolumn{2}{|c|}{$\begin{array}{c}\text { Return from } \\
\text { Social Security }\end{array}$} & \multicolumn{2}{c|}{ Median Voter's Age } \\
\hline & 2000 & 2050 & 2000 & 2050 \\
\hline France & $2.7 \%$ & $1.3 \%$ & 43 & 53 \\
\hline Germany & $3.6 \%$ & $2.2 \%$ & 46 & 55 \\
\hline Italy * & $2.6 \%$ & $1.3 \%$ & 44 & 57 \\
\hline Spain & $4.0 \%$ & $1.4 \%$ & 44 & 57 \\
\hline UK & $3.1 \%$ & $0.7 \%$ & 45 & 53 \\
\hline US & $3.3 \%$ & $2.2 \%$ & 47 & 53 \\
\hline * Data refer to 1992 rather than 2000 \\
\hline Source: Authors' calculations \\
\hline
\end{tabular}

In this section, we focus on two crucial aspects of the aging process: 1) the increase in the ratio of retirees to workers - the dependency ratio - which reduces the average profitability of the unfunded social security system; and 2) the increased political influence of the elderly voters. The former effect would tend to induce the agents to reduce the size of the system, by substituting their claims towards future pensions with more private savings. Notice however that, if individual longevity - and hence the period during which retirees receive pension benefits - increases substantially, they may not be willing to reduce the size of the system. The latter aspect leads to larger systems, since an aging electorate increases the relevance of pension spending on the agenda of the policy-makers. The relative magnitude of these two effects is summarized in table 6 , where the long term

\footnotetext{
${ }^{9}$ Notice, however, that higher wages may also increase pension benefits, if these are indexed to wage growth (rather than to inflation).

${ }^{10}$ According to our (unreported) simulations with different productivity growth rates, this occurs only in the UK.
} 


\section{BOX3 : SIMULATION METHODOLOGY}

Our simulation methodology consists of two stages: (I) calibration of the model; and (II) simulation of the model under different policy specifications.

Stage I Our general equilibrium politico-economic model (described in the appendix A) is calibrated to the economic, demographic and political aspects and to the social security system of each of our six countries (see box 1 for the details of the calibration). The aim of this first stage is to characterize these countries as if they were - in the year ${ }^{*} 2000$ - in their initial steady state. This exercise allows us to calibrate - for each country - the values of some key parameters of the model (reported in a table in box 1). For each country, the first line in Tables 7 and 8 provides the country's characteristics as calibrated in the initial steady state.

Stage II We retain the calibrated parameters and feed the model with forecasted values of economic, demographic and political variables - such as, individual survival probabilities, population growth rate, productivity growth rate and median voter's age - for the year 2050, as reported in the table below. With this new set of parameters, the model simulates - in a new steady state - the political sustainability of the social security system, for different values of the (exogenous) retirement age. In particular, it determines the contribution tax rate chosen by the median voter in the year 2050. For each country, all lines in Tables 7 and 8, but the first one, provide the results of our simulations in terms of social security contribution rate, replacement rate and employment rate (only in table 8), in a new steady state, for given values of our policy variables: the retirement age.

\section{Forecasted Parameters of the Politico-Economic Model}

\begin{tabular}{|l|c|c|c|c|c|c|}
\hline & $\underline{\text { France }}$ & $\underline{\text { Germany }}$ & $\underline{\text { Italy }}$ & $\underline{\text { Spain }}$ & $\underline{\text { U.K. }}$ & $\underline{\text { U.S. }}$ \\
\hline Population growth & $-0.05 \%$ & $-1.44 \%$ & $-1.5 \%$ & $-1.69 \%$ & $-1.0 \%$ & $0.25 \%$ \\
\hline Productivity growth & $1.8 \%$ & $1.8 \%$ & $1.8 \%$ & $1.8 \%$ & $1.7 \%$ & $1.94 \%$ \\
\hline Median voter's age & 53 & 55 & 57 & 57 & 53 & 53 \\
\hline
\end{tabular}

Source: see Appendix B

\footnotetext{
* For Italy, the initial steady state is taken to be in 1992, that is before the Amato and Dini reforms. We will address the effects of the reforms in section 5.1 .
} 
returns on social security take into account the expected changes in the demographics (see table 2 for the data on the dependency ratio).

Table 7. The direct impact of aging: Results of simulations

\begin{tabular}{|c|c|c|c|c|c|}
\hline Countries & Year & $\begin{array}{l}\text { Median Voter's } \\
\text { Age }\end{array}$ & $\begin{array}{c}\text { Effective } \\
\text { Retirement Age }\end{array}$ & $\begin{array}{l}\text { Social Security } \\
\text { Contribution Rate }\end{array}$ & $\begin{array}{l}\text { Replacement } \\
\text { Rate }\end{array}$ \\
\hline \multirow[t]{3}{*}{ France } & 2000 & 43 & 61 & $22.4 \%$ & $64.6 \%$ \\
\hline & 2050 & 53 & 61 & $38.7 \%$ & $65.8 \%$ \\
\hline & 2050 & 53 & 65 & $33.0 \%$ & $80.3 \%$ \\
\hline \multirow[t]{3}{*}{ Germany } & 2000 & 46 & 61 & $23.8 \%$ & $68.3 \%$ \\
\hline & 2050 & 55 & 61 & $37.7 \%$ & $55.4 \%$ \\
\hline & 2050 & 55 & 65 & $32.6 \%$ & $81,2 \%$ \\
\hline \multirow[t]{3}{*}{ Italy } & 1992 & 44 & 58 & $38.0 \%$ & $73.6 \%$ \\
\hline & 2050 & 57 & 58 & $51.6 \%$ & $57.2 \%$ \\
\hline & 2050 & 57 & 65 & $39.7 \%$ & $77.5 \%$ \\
\hline \multirow{3}{*}{ Spain } & 2000 & 44 & 62 & $18.8 \%$ & $60.0 \%$ \\
\hline & 2050 & 57 & 62 & $42.6 \%$ & $60.5 \%$ \\
\hline & 2050 & 57 & 65 & $37.6 \%$ & $71.4 \%$ \\
\hline \multirow{3}{*}{$\begin{array}{c}\text { United } \\
\text { Kingdom }\end{array}$} & 2000 & 45 & 63 & $14.5 \%$ & $75.8 \%$ \\
\hline & 2050 & 53 & 63 & $33.2 \%$ & $95.2 \%$ \\
\hline & 2050 & 53 & 65 & $31.1 \%$ & $114.3 \%$ \\
\hline \multirow{3}{*}{$\begin{array}{l}\text { United } \\
\text { States }\end{array}$} & 2000 & 47 & 63 & $9.7 \%$ & $41.9 \%$ \\
\hline & 2050 & 53 & 63 & $21.6 \%$ & $55.7 \%$ \\
\hline & 2050 & 53 & 65 & $18.3 \%$ & $53.9 \%$ \\
\hline urce: Au & alculc & & & & \\
\hline
\end{tabular}

Table 7 shows the results of our simulations. We compute the social security contribution rate as chosen by the majority of the voters (see section 3 ) in the year 2000, which we take to be our base year ${ }^{11}$, and in the year 2050, for different retirement ages. In fact, since - as surveyed in section 2.3 - several countries have adopted social security reform's measures aimed at increasing the effective retirement age, we simulate the social security contribution rate that would emerge in the political process if these measures were adopted in all countries and the retirement age was 65 years. For each country, the first line in Table 7 provides the country's characteristics as calibrated in the initial steady state, i.e., in the year 2000, whereas the following lines provide the results of our simulations in terms

\footnotetext{
${ }^{11}$ In Italy, the base year is 1992, since we aim at evaluating the political sustainability of the reforms that took place in 1992 and 1995 (see also D’Amato and Galasso, 2002).
} 
of social security contribution rate and replacement rate, in a new steady state, for given values of our policy variables: the retirement age (see also section 6.1.)

Table 8. Disentangling the two effects: Results of simulations

\begin{tabular}{|c|c|c|c|c|}
\hline Countries & Year & $\begin{array}{c}\text { Median } \\
\text { Voter's Age }\end{array}$ & $\begin{array}{c}\text { Social Security } \\
\text { Contribution Rate }\end{array}$ & $\begin{array}{c}\text { Replacement } \\
\text { Rate }\end{array}$ \\
\hline \multirow[t]{3}{*}{ France } & 2000 & 43 & $22.4 \%$ & $64.6 \%$ \\
\hline & 2050 & 43 & $18.2 \%$ & $30.9 \%$ \\
\hline & 2050 & 53 & $38.7 \%$ & $65.8 \%$ \\
\hline \multirow[t]{3}{*}{ Germany } & 2000 & 46 & $23.8 \%$ & $68.3 \%$ \\
\hline & 2050 & 46 & $15.0 \%$ & $22.1 \%$ \\
\hline & 2050 & 55 & $37.7 \%$ & $55.4 \%$ \\
\hline \multirow[t]{3}{*}{ Italy } & 1992 & 44 & $38.0 \%$ & $73.6 \%$ \\
\hline & 2050 & 44 & $36.5 \%$ & $40.5 \%$ \\
\hline & 2050 & 57 & $51.6 \%$ & $57.2 \%$ \\
\hline \multirow[t]{3}{*}{ Spain } & 2000 & 44 & $18.8 \%$ & $60.0 \%$ \\
\hline & 2050 & 44 & $8.5 \%$ & $12.0 \%$ \\
\hline & 2050 & 57 & $42.6 \%$ & $60.5 \%$ \\
\hline \multirow{3}{*}{$\begin{array}{c}\text { United } \\
\text { Kingdom }\end{array}$} & 2000 & 45 & $14.5 \%$ & $75.8 \%$ \\
\hline & 2050 & 45 & $18.8 \%$ & $53.9 \%$ \\
\hline & 2050 & 53 & $33.2 \%$ & $95.2 \%$ \\
\hline \multirow{3}{*}{$\begin{array}{l}\text { United } \\
\text { States }\end{array}$} & 2000 & 47 & $9.7 \%$ & $41.9 \%$ \\
\hline & 2050 & 47 & $15.7 \%$ & $40.5 \%$ \\
\hline & 2050 & 53 & $21.6 \%$ & $55.7 \%$ \\
\hline
\end{tabular}

The overall assessment is that the political aspect - the increased political influence of the elderly voters - dominates in all countries, albeit with some differences. In fact, in all countries the social security contribution rate - hence the size of the system - increases. However, an increase in the retirement age mitigates this rise.

To disentangle the two effects - average profitability and political element- we simulate the model with the 2050 values of the demographic and economic variables, but keeping the median voter's age (and the retirement age) at its 2000 level. These simulations provide a measurement of the relative size of the effect on the average profitability. Table 8 summarizes the results. For each country, the first line characterizes the system at its initial steady state (as in table 7), the second line reports the size of the effect on the average profitability, while the third line shows the overall effect (as in table 7). In France, 
Germany and Spain, the negative profitability effect is sizable: a pivotal individual with the same age as the 2000 median voter, but facing the demographic and economic trends expected for the year 2050, would reduce the size of the social security system by more than $4 \%$. However, the political effect dominates and induces a hike in the tax rate by more than $20 \%$. In Italy, the political effect is still sizeable, while the average profitability effect is much weaker. UK and US display a different pattern. The average profitability effect turns out to be positive, as a pivotal individual with the same age as the 2000 median voter, under the 2050 expected demographic and economic dynamics would indeed increase the social security tax rate. This is because the aging process - and hence the change in the dependency ratio - is moderate and the effect on the increase in the individual longevity prevails. The political effect is also positive, thereby causing a further hike in the tax rate, more relevant in the UK.

According to our simulations, a more pronounced population aging process and a smaller initial social security system lead to larger variations. If the retirement age remains at the year 2000 level, the largest increase (almost 20\% of GDP) takes place in Spain, the fastest aging country in our sample ${ }^{12}$. In Italy, the next fast aging country, the increase is less dramatic, perhaps because of the large initial size of the system.

It is interesting to notice that, despite the hike in the contribution rate, in Germany and Italy the replacement rate, i.e., the ratio between the pension benefit and the (latest) wage income, decreases. This is due to the increase in the dependency ratio: although social security tax rates are higher, there are fewer workers contributing to the system and more retirees drawing pension benefits. In Germany and Italy, the overall generosity of the system, as measured by the replacement rate, hence decreases. In all other countries, the increase in the contribution tax rate dominates and the systems become more generous, as the replacement rates rise.

The effects of the policy measure we examined are sizeable. An increase in the effective retirement age leads to a reduction of the size of the system, i.e., in the contribution tax rate, since it increases the contribution period for the median voter, while reducing the period during which she will draw the pension benefits (see figure 2). An

\footnotetext{
${ }^{12}$ Although this result may sound intuitive, it is important to stress that the two effects of aging - the decrease in the long term return from the system and the increase in the median voter's age - pull in different directions, thereby leading - in principle - to an ambiguous effect.
} 
increase in the retirement age to 65 years is particularly effective in those countries with a low initial effective retirement age, such as Italy, where the tax rate would be reduced by $12 \%$ - from $51.6 \%$ to $39.7 \%$; however, the impact would also be large -around 5\%- in Spain, France and Germany. Notably, despite reducing the contribution rate, in all countries but the US, this policy also manages to increase the generosity of the system, i.e., the replacement rate. This is due to the fact that social security dependency ratio, i.e., the ratio of retirees to workers, is reduced. Germany would enjoy the largest effect, with an increase in the replacement rate by more than $25 \%$, followed by Italy (20\%) and the UK $(19 \%)$.

Figure 6: Consumption Profile by Age in France

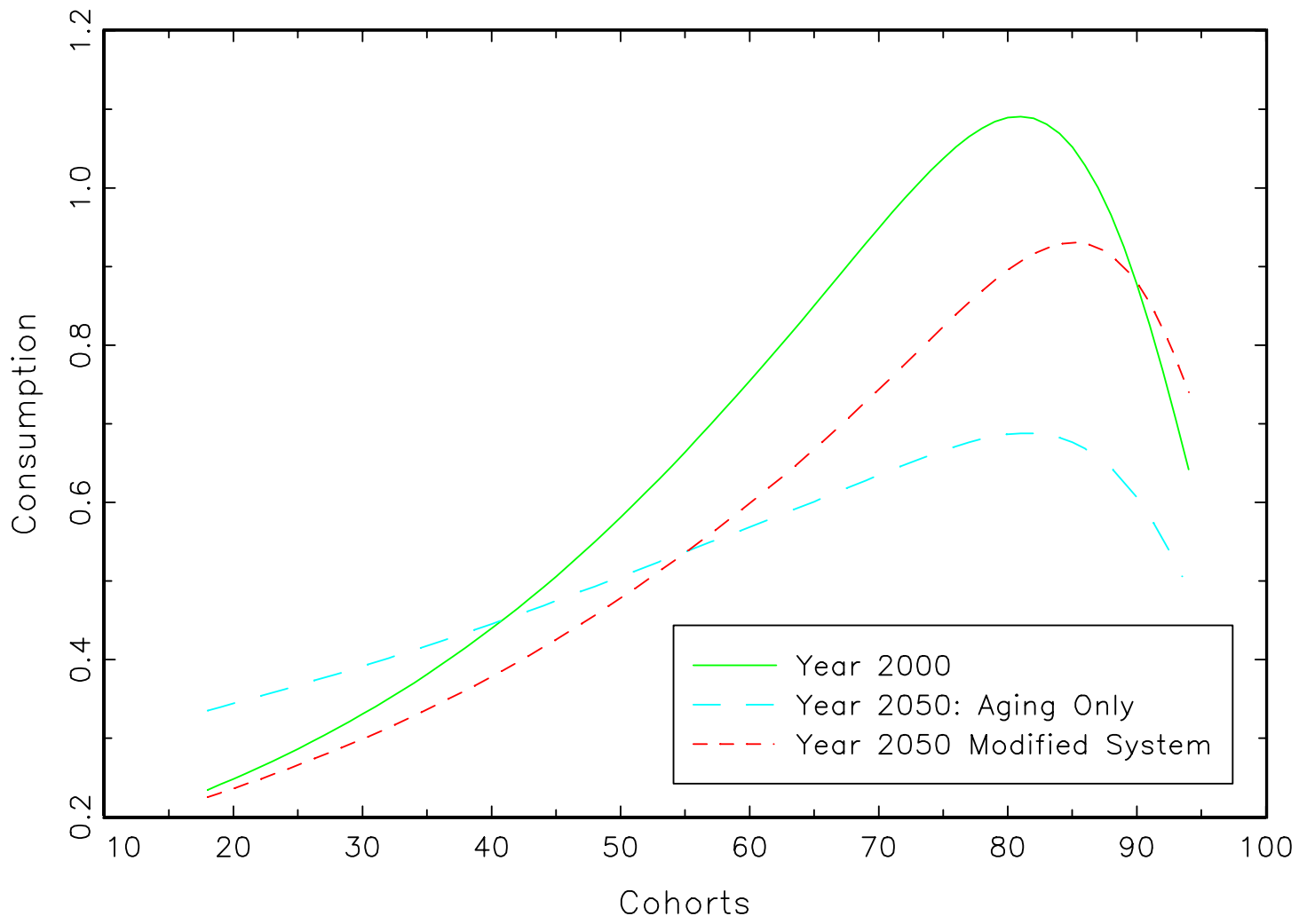

The aging process and the changes in the social security system thereby induced affect the agents' economic decisions in several dimensions. First, by changing the age composition of the population, aging leads to a higher stock of capital, and hence to higher wages and lower returns from capital. Aging also affects the long run returns from the social security system through the increase in the dependence ratio: for a given contribution rate, individuals will receive lower pension benefits. Moreover, as individual expected longevity increases, consumers will be induced to save more for (very) old age 
consumption, as they will be more likely to reach this old age. The overall effect - mainly due to the decrease in pension benefits - is a reduction in the individual lifetime wealth. Being poorer, individuals will have to consume less. In fact, as shown in figure 6 for the case of France, the consumption profile ${ }^{13}$ shifts down, because of the decrease in the lifetime wealth, and tilts towards more consumption in old age, due to the increased longevity ${ }^{14}$. Second, the modifications of the social security system provide additional effects that partially counterbalance the impact of aging. In particular, the increase in the contribution rate reduces the stock of capital, since agents reduce their savings to compensate for the higher pension benefits. Moreover, if the effective retirement age is raised, the corresponding increase in the replacement rate - due also to the rise of the contribution rate - limits the drop in lifetime wealth. Figure 6 shows that the consumption profile tilts and shifts upward, as compared to the case of aging with an unchanged social security system, although it remains below the year 2000 level. Unsurprisingly, this consumption profile - induced by the political decision of a 53 years old median voter - is even more tilted towards more old age consumption.

\subsection{Employment and Tax Distortions}

The previous section suggested that the increased political influence of the elderly voters, induced by the aging process, will lead to larger social security system, albeit not necessarely to more generous pension benefits - see Germany and Italy- because of the increase in the dependency ratio. In this section, we explore the possibility that the economic environment may feature some "self-defensive" elements against these political decisions. In particular, we concentrate on the role of the labor market. We consider an environment in which the employment rate responds to changes to the wages and to the social security contribution rates (see figure 7). Hence, a higher (combined employeremployee) tax rate or a lower wage decrease the opportunity cost of leisure and will tend to decrease the agents' labor supply. Specifically, our model identifies the representative

\footnotetext{
${ }^{13}$ The scale of consumption on the vertical axis of figure 6 may be related to an annual average income, which is equal to 0.671 in the year 2000, to 0.641 in the year 2050 (aging only) and to 0.643 in the year 2050 (modified system)

${ }^{14}$ Youth consumption increases as well, due to a reduction in the interest rate.
} 
worker's labor supply decision - for every age - with the average employment rate by age (see box 1 on calibration for more details).

Figure 7: Employment Rate by Age in Italy

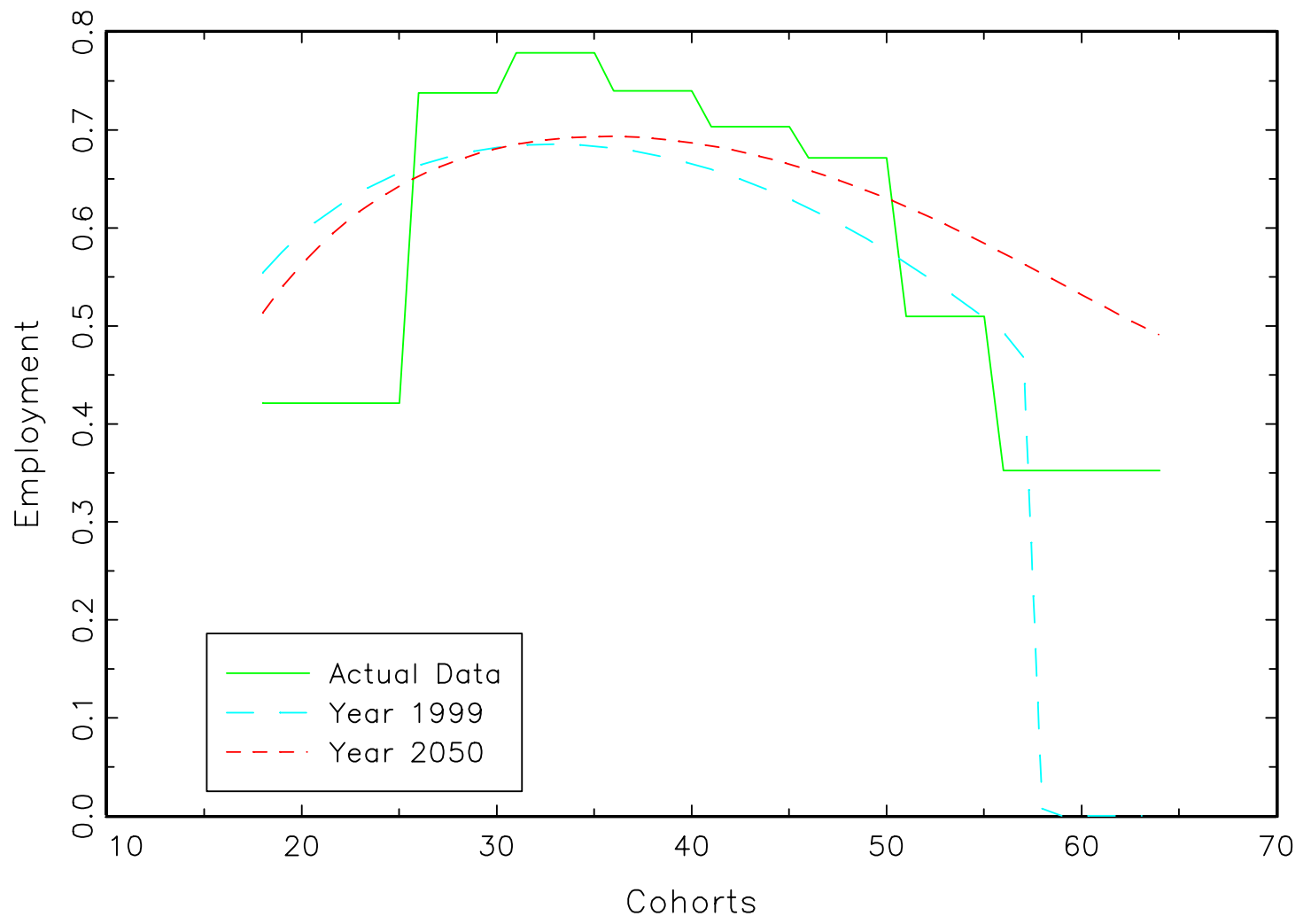

Do these political forces - characterized by an older median voter - dominate the negative effect of the aging process on the social security returns, even in an economic environment featuring such distortion?

The results of our simulations, shown in table 9, suggest that the political aspect is still very relevant, albeit less than in the previous scenario. With the retirement ages at their 2000 levels, the social security contribution rates rise in all countries. However, the magnitude of these changes is everywhere of a lower scale, but in France. In Italy and Spain -the two fastest aging countries- these labor market observations would moderate the hike in the social security tax rate, respectively by $4 \%$ and $6.8 \%$. The increase in the size of the system is also reduced in Germany (by $2 \%$ ), in the UK (by $1.5 \%$ ) and in the US (by almost 1\%). Suprisingly, the introduction of endogenous labor decisions would magnify the increase of the tax rate in France (by 2.2\%). This counterintuitive result is due to the large 
increase in the wages induced by the aging process through an increase in the stock of capital. Because of the higher wages, the employment rate increases thereby counterbalancing the negative effect (on the labor supply) of the tax distortion.

Table 9. Employment and tax distortions. Results of simulations

\begin{tabular}{|c|c|c|c|c|c|c|}
\hline Country & Year & $\begin{array}{c}\text { Median } \\
\text { Voter's Age }\end{array}$ & $\begin{array}{c}\text { Effective } \\
\text { Retirement Age }\end{array}$ & $\begin{array}{c}\text { Social Security } \\
\text { Contribution Rate }\end{array}$ & $\begin{array}{c}\text { Replacement } \\
\text { Rate }\end{array}$ & $\begin{array}{c}\text { Employment } \\
\text { Rate }\end{array}$ \\
\hline \multirow[t]{3}{*}{ France } & 2000 & 43 & 61 & $22.4 \%$ & $67.2 \%$ & $72.1 \%$ \\
\hline & 2050 & 53 & 61 & $40.9 \%$ & $70.4 \%$ & $72.7 \%$ \\
\hline & 2050 & 53 & 65 & $35.0 \%$ & $81.6 \%$ & $72.1 \%$ \\
\hline \multirow[t]{3}{*}{ Germany } & 2000 & 46 & 61 & $23.8 \%$ & $67.6 \%$ & $81.7 \%$ \\
\hline & 2050 & 55 & 61 & $35.7 \%$ & $50.0 \%$ & $81.9 \%$ \\
\hline & 2050 & 55 & 65 & $29.2 \%$ & $55.4 \%$ & $81.1 \%$ \\
\hline \multirow[t]{3}{*}{ Italy } & 1992 & 44 & 58 & $38.0 \%$ & $75.7 \%$ & $62.6 \%$ \\
\hline & 2050 & 57 & 58 & $47.6 \%$ & $50.2 \%$ & $64.1 \%$ \\
\hline & 2050 & 57 & 65 & $37.0 \%$ & $67.4 \%$ & $62.0 \%$ \\
\hline \multirow[t]{3}{*}{ Spain } & 2000 & 44 & 62 & $18.8 \%$ & $77.4 \%$ & $60.3 \%$ \\
\hline & 2050 & 57 & 62 & $35.8 \%$ & $61.5 \%$ & $60.4 \%$ \\
\hline & 2050 & 57 & 65 & $32.1 \%$ & $83.7 \%$ & $58.8 \%$ \\
\hline \multirow{3}{*}{$\begin{array}{c}\text { United } \\
\text { Kingdom }\end{array}$} & 2000 & 45 & 63 & $14.5 \%$ & $74.8 \%$ & $73.4 \%$ \\
\hline & 2050 & 53 & 63 & $31.7 \%$ & $91.6 \%$ & $72.5 \%$ \\
\hline & 2050 & 53 & 65 & $29.0 \%$ & $104.2 \%$ & $71.9 \%$ \\
\hline \multirow{3}{*}{$\begin{array}{l}\text { United } \\
\text { States }\end{array}$} & 2000 & 47 & 63 & $9.7 \%$ & $46.4 \%$ & $80.5 \%$ \\
\hline & 2050 & 53 & 63 & 20.7 & $57.3 \%$ & $81.2 \%$ \\
\hline & 2050 & 53 & 65 & 18.7 & 60.0 & $80.8 \%$ \\
\hline
\end{tabular}

Interestingly, our simulations suggest that, despite the aging process, if the policy measures adopted in many of these countries are effective in rising the retirement age to 65 years, the size of the system may indeed be lower than in 2000. This is the case of Italy. In all other countries, the contribution rate would still be higher than in the year 2000, but the simulations show that this policy measure would be more effective than our previous simulations suggested (see table 7).

Regarding the effects on the generosity of the system, as in the previous scenario, the replacement rate would decrease in some countries (Germany, Italy and Spain), despite the rise in the contribution rate. Indeed, in this new economic environment, the drop would be even larger. In fact, together with the increase in the dependency ratio, there would also 
be a reduction in the labor supply - and hence in the social security tax base - due to the increase in the contribution rate.

Figure 8: Consumption Profile by Age in France

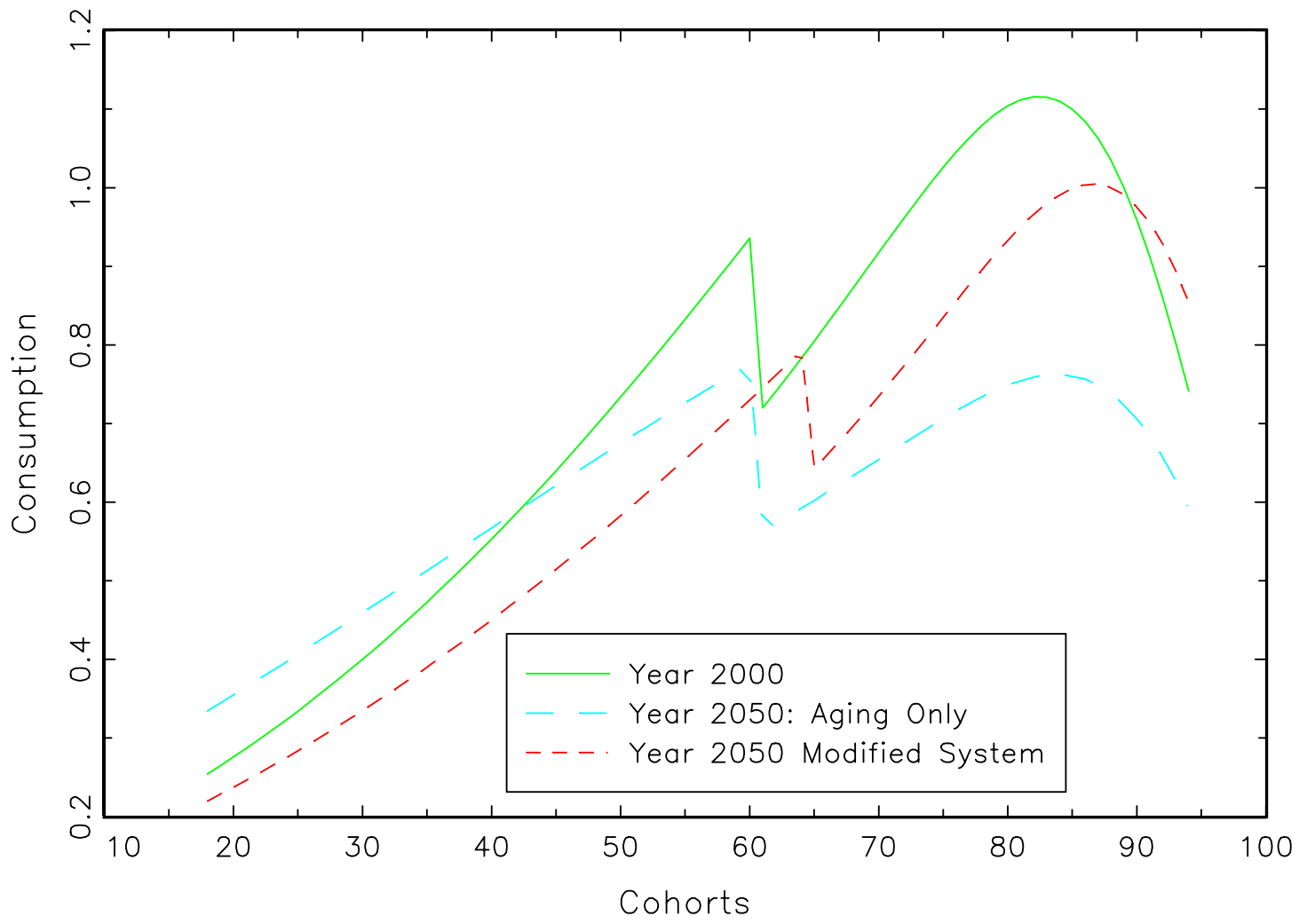

In this new economic scenario, we can analyze the effects of the aging process, such as the increase in the wage rate, and the changes in the social security system thereby induced, on the labor market, and in particular on the employment rate by age groups. Figure 7 displays the actual employment profile by age in Italy and the simulated profile for the year 2000 and for the year 2050, with an effective retirement age of 65 years. An interesting feature appears: the employment rate profile tilts towards lower employment in youth and higher employment in old age. This reshuffling of the labor supply over the lifecycle - which is not specific of the Italian case, but common to all other countries - is due to several combined effects. The aging process leads to a higher stock of capital, and hence to higher wages. This wage rise - accompanied in the case of Italy by a reduction of the contribution rate - induces an increase in the labor supply, which takes place in the second part of the agents' working life, when labor efficiency and hence wages are higher, because of the steepness in the wage profile. It is important to stress that this tilt in the 
employment profile towards more labor participation by the elderly workers and lower employment among the young is due to individual labor supply decisions ${ }^{15}$. A more detailed description of the labor market, accounting for the role of the unions and for existing employment protection legislations, may be able to capture additional effects.

Finally, the effects of the aging process and of the changes in the social security system on the agents' economic decisions are analogous to the previous case. The individual lifetime wealth is reduced and, as shown in figure 8 for France, the consumption profile ${ }^{16}$ shifts down and tilts towards more old age consumption.

\section{Country-Specific Features}

\subsection{Intragenerational Redistribution and Parametric Reforms}

The simulation exercise carried out in section 4 concentrates on the intergenerational aspects of the social security system. In an aging environment, this clearly represents the crucial feature. However, other dimensions of heterogeneity may play a role in determining the political sustainability of a social security system, in particular, when parametric reforms occur as in Italy in 1992 and 1995 and in the UK in 1999.

In the UK, the system entails a strong element of intragenerational redistribution (see section 2.2), typically from the high to the low income individuals. These features affect the individual voting behavior and hence the median voter's identity ${ }^{17}$ and the equilibrium social security contribution rate. Even in countries with a less redistributive system such as Italy, these considerations may play a role. In 1995, with the Dini reform (see section 2.3 and table 4) the Italian system switched from a defined benefit to a defined contribution scheme. This radical shift affected the generosity of the pension benefits depending - among other things - on the individual lifetime income profile and contribution history.

A recent politico-economic literature has argued that the type of the pension system may affect the direction of the reform policies, particularly in the case of retrenchment.

\footnotetext{
${ }^{15}$ In our model, firms' labor demand does not depend on workers' age or seniority, and wage depends on the workers' labor efficiency units.

${ }^{16}$ As in figure 6, the scale of consumption on the vertical axis may be related to the annual average lifetime income, which is now equal to 0.745 in the year 2000, to 0.743 in the year 2050 (aging only) and to 0.704 in the year 2050 (modified system)

${ }^{17}$ The median voter may not coincide with the individual with the median age.
} 
Bonoli (2000) has suggested that in less resistributive - Bismarckian - pension systems, reform policies typically aim at reducing the degree of redistribution, whereas in more redistributive - Beveridgean - schemes, reforms favor the low-income retirees, and hence increase the degree of redistribution.

In this section, we discuss the redistributive effects of the Dini reform in Italy and of the Welfare Reform and Pension Act in the UK, and their impact on the future political sustainability of the Italian ${ }^{18}$ and of the British social security system.

To assess the role of intragenerational redistribution in the Italian 1995 Dini reform, D'Amato and Galasso (2002) partition individuals by age - from 18 to 95 years old - and education - low, medium and high. Within each age cohort, the education level affects retirement age, working history, income profile, survival probability and participation rate at elections. In particular, more educated individuals retire later, enter the labor market at a later age, live longer, enjoy steeper income profiles and participate more at elections.

Using a model with intragenerational heterogeneity, D’Amato and Galasso (2002) estimate higher increases in the social security tax rate than our simulations predicted in section 4.2. With the retirement ages at their 1992 (pre-reforms) level - 57 years for low, 56 for medium and 58 for high educated individuals - in 2050 the social security contribution rate chosen by the majority of the voters would be equal to $61 \%$ (as opposed to $51.6 \%$ in our simulations at section 4.2). The specification in D'Amato and Galasso (2002) allows to examine the effects of the reform on the generosity of the pension benefit and highlights the existence of a redistributive effect. In fact, the replacement rate increases for the low and medium educated people - respectively from $59 \%$ to $69 \%$ and from 69 to $77 \%$ - and decreases from $69 \%$ to $61 \%$ for the high educated individuals. Hence, despite the goal of providing a tighter link between contributions and pension benefits -through the shift from defined benefit to defined contribution scheme- the reform has introduced an element of intragenerational redistribution ${ }^{19}$, from high to medium and low educated agents, in the system. Moreover, D'Amato and Galasso's (2002)

simulations confirm our results (see table 7) on the crucial importance of the retirement age in affecting the political choice on the size of the system: an increase in the retirement age

\footnotetext{
${ }^{18}$ See D'Amato and Galasso (2002).

${ }^{19}$ Peracchi and Rossi (1996) argue that this redistributive element is due to the steepness of the high-educated income profile.
} 
to 65 for all individuals would increase the tax rate to $48.9 \%$ (rather than $61 \%$ ), while increasing the replacement rate.

In 1999, the Welfare Reform and Pension Act modified the second tier - the earning related element - of the British pension system. While the Basic State Pension (BSP) - a flat rate pension - has remained unchanged, this reform has substituted the existing State Earnings Related Pension System (SERPS) with a new benefit, the State Second Pension (S2P). Unlike the SERPS, which was linked to the retirees' previous earnings, the S2P is a flat rate pension provided on top of the BSP. Clearly, this reform aimed at reshaping the pension system in a more redistributive way.

To assess the redistributive effects of this reform, we partition the individuals by age and education - low and high - and we model the British social security system as described in the Appendix A to account for the different pension benefits. A particular feature of the British system is that individuals may choose to opt out of the second tier of the pension scheme - SERPS or, after the reform, S2P. In this case, their contributions (as well as their employee's contributions) to the pension system are reduced, but they only receive the basic benefit - the BSP - and no SERPS (or S2P). Consistently with data from the UK Department of Welfare and Pension, we assume that the high-educated agents contract out of the system, while low-educated individuals remain in the system and receive both pension benefits, BSP and SERPS or S2P.

We calibrate the model to the year 2000 data - taken to be the initial steady state and then run two sets of simulations with the year 2050 demographic, economic and political elements: one for the reformed system - consisting of BSP and S2P; and one for a hypothetical "unreformed" system - composed of BSP and SERPS. The results, summarized in table 10, suggest that the reform will lead to an increase in the size of the system, while at the same time increasing its generosity towards the low-educated retirees, as measured by the replacement rate. With the retirement age at its year 2000 level - 63 years for both low and high educated individuals - the normal tax rate (i.e., the tax rate paid by those who do not opt out) would increase from $17.1 \%$ in 2000 to $39 \%$, in absence of a reform, and to $43 \%$, with the reform. The substitution of the SERPS with the S2P would mainly benefit the low-educated retirees, whose replacement rate would increase from 
$66.7 \%$ in 2000 to $85.4 \%$ in 2050 , while the replacement rate of the high-educated would be almost unaffected.

Table 10. The UK 1999 Reform

\begin{tabular}{|c|c|c|c|c|c|}
\hline Year & Scheme & $\begin{array}{c}\text { Effective } \\
\text { Retirement Age }\end{array}$ & $\begin{array}{c}\text { Social Security } \\
\text { Contribution Rate }\end{array}$ & $\begin{array}{c}\text { Replacement } \\
\text { Rate (Low) }\end{array}$ & $\begin{array}{c}\text { Replacement } \\
\text { Rate (High) }\end{array}$ \\
\hline 2000 & BSP \& SERPS & 63 & $17.1 \%$ & $66.7 \%$ & $48.5 \%$ \\
\hline 2050 & BSP \& SERPS & 63 & $39.0 \%$ & $75.3 \%$ & $54.5 \%$ \\
\hline 2050 & BSP \& SERPS & 64 & $36.5 \%$ & $78.1 \%$ & $58.0 \%$ \\
\hline 2050 & BSP \& SERPS & 65 & $34.3 \%$ & $81.4 \%$ & $62.2 \%$ \\
\hline 2050 & BSP \& S2P & 63 & $43.0 \%$ & $85.4 \%$ & $55.0 \%$ \\
\hline 2050 & BSP \& S2P & 64 & $40.0 \%$ & $88.2 \%$ & $58.5 \%$ \\
\hline 2050 & BSP \& S2P & 65 & $37.6 \%$ & $92.0 \%$ & $62,7 \%$ \\
\hline
\end{tabular}

Source: Authors' calculations

To summarize, the introduction of elements of intragenerational heterogeneity in the analysis does change somewhat the picture obtained by our simulations at table 7 . In the case of Italy, D'Amato and Galasso's (2002) results confirm our view that the reforms of the 90s may help in containing the expansion of the social security expenditure, if the retirement age increases, as required by the reforms. Interestingly, the use of a model that accounts intragenerational redistributive elements captures an unexpected pattern of redistribution in the Dini reform: despite the move from a DB to a DC scheme, the higheducated retirees' replacement rate decreases, while that of low and middle-educated agents increases. This observation is at odds with Bonoli's (2000) view that in a Bismarckian system, reform's efforts lead to less redistribution. For the UK, the simulations results obtained using a model with intrageneration heterogeneity differ in magnitude from those provided in section 4.2 (table 7). If we account for the different role that the pension system plays for low and high educated agents, with high-educated individuals being able to contract out of the second tier, the size of the system chosen by the median voter in the year 2050 is larger, e.g., $37.6 \%$ vs. $31.1 \%$ for a 65 years retirement age (see tables 7 and 10). Hence, the change in the design of the system, aimed at providing more income security for the low-income retirees, modifies the political supports among the voters and leads to a large system ${ }^{20}$.

\footnotetext{
${ }^{20}$ This last result is in line with Bonoli's (2000) view that in Beveridgean systems reforms exacerbate the redistributive component.
} 
The different results in terms of political sustainability of these two reforms, with the possible long-run retrenching of the Italy system and the expected increase in the size of British system, suggest that the existence of a Beveridgean or of a Bismarckian scheme may play a role in the long term development of the social security system. This issue is addressed in the next section.

\subsection{Bismarckian versus Beveridgean Systems}

As previously argued (see sections 2.2 and 5.1) social security systems may differ in their degree of within-cohort redistribution. A synthetic measure of the intragenerational component is given by the difference among the replacement rates at different income levels. Since contributions are typically proportional to earnings, if replacement rates are constant across income classes, the system does not redistribute within cohort, while if the replacement rates are low for higher earners and decrease with income levels, the system redistributes from high to low income individuals. Countries with a system of the former type are called "Bismarckian", the latter "Beveridgean". Table 11 suggests that Italy, France, Germany and Spain have high replacement rates at all levels of income - hence they have a Bismarckian systems- while the UK and the US systems provide high replacement rates for higher earners - hence being Beveridgean- .

Table 11 : Bismarckian versus Beveridgean systems

\begin{tabular}{|l|l|l|l|l|l|l|l|}
\hline \multicolumn{2}{|c|}{} & France & Germany & Italy & Spain & $\begin{array}{l}\text { United } \\
\text { Kingdom }\end{array}$ & $\begin{array}{l}\text { United } \\
\text { States }\end{array}$ \\
\hline $\begin{array}{l}\text { Replacement Rate } \\
\text { Low-income }\end{array}$ & 1.0295 & 0.67 & 1.05 & 1.07 & 2.16 & 0.64 \\
\hline $\begin{array}{l}\text { Replacement Rate } \\
\text { Middle-income }\end{array}$ & 0.83 & 0.72 & 0.84 & 0.87 & 0.61 & 0.54 \\
\hline $\begin{array}{l}\text { Replacement Rate } \\
\text { High-income }\end{array}$ & 0.74 & 0.75 & 0.79 & 0.85 & 0.51 & 0.32 \\
\hline Gini index & 32.7 & 30 & 27.3 & 32.5 & 36.1 & 40.8 \\
\hline $\begin{array}{l}\text { Pension funds assets as \% of } \\
\text { GDP (1993) }\end{array}$ & 3.4 & 5.8 & 1.2 & 2.2 & 79.4 & n.a. \\
\hline $\begin{array}{l}\text { Pension funds 1984-93. } \\
\text { Average Nominal Rates of } \\
\text { Return (real in parenthesis) }\end{array}$ & n.a. & $9.4(7.1)$ & n.a. & $13.8(7)$ & $15.5(10.2)$ & n.a. \\
\hline $\begin{array}{l}\text { Total value of Pension funds } \\
\text { (US \$ billions) 2000 }\end{array}$ & 85 & 188 & n.a. & n.a. & 1256 & n.a. \\
\hline $\begin{array}{l}\text { Sources. Replacement Rates: France, Italy, Spain and United Kingdom: Conde Ruiz and Profeta (2002); Germany } \\
\text { and United States: Disney and Johnson (2001). Gini Index: World Development Indicators, World Bank 2000; } \\
\text { Pension funds: Green Paper EC 1997 and Watson Whyat. }\end{array}$ \\
\hline
\end{tabular}


Table 11 shows that in 2000 UK and US, the Beveridgean systems, feature the lowest tax rates, and thus the smaller pension systems. Moreover, our simulations (see tables 7 and 9) suggest that in 2050 these countries will still enjoy - together with France the lowest tax rates.

These simulations, however, are more closely related to the functioning of the Bismarckian systems, while they abstract from the specific features of the Beveridgean schemes. In particular, by providing a flat pension benefit, Beveridgean systems target mainly low-income individuals and manage to keep the social security contribution tax and hence the size of the system - relatively small. As suggested in section 5.1, low-income voters clearly support this redistributive feature. Interestingly, also high income individuals may prefer this scheme, in which they compensate the pension benefits with low contributions. In fact, this lower tax burden on earnings allows them to free up resources to be invested more profitably on the private market (as witnessed by the opting out in the UK). As suggested by Conde Ruiz and Profeta (2002), these Beveridgean systems may hence be supported by a voting coalition of the extreme (as in Epple and Romano, 1996), featuring low and high-income individuals.

How would the aging process modify the social security system in this richer environment? Our previous simulations - see tables 7 and 9 - suggest that the political feature - the aging of the electorate - dominates the negative effect on the returns and leads to higher tax rates. According to Conde Ruiz and Profeta's (2002) line of reasoning, an increase in the size of the system may lead to a change in its degree of redistribution ${ }^{21}$. In particular, with a larger tax burden, high-income individuals have less incentive to support a Beveridgean system, since the low flat benefit is now associated with higher contributions, and may thus shift their support in favor of a more Bismarckian scheme. Hence, aging would induce an increase in the size of the system and a movement towards a more Bismarckian scheme.

\subsection{Family-Ties}

Simulations at section 4 are based on the implicit assumption that social security voting decisions are taken within a family unit composed of two individuals: husband and wife. 
This assumption - perhaps realistic in societies in which the household composition is rather limited - may however turn out to be misleading in societies with stronger family ties.

A recent study by CSIS and Watson Wyatt (2003) shows that in some countries such as Japan (50\%), Italy (42\%) and Spain (40\%) - a significant portion of elderly individuals live with their adult children ${ }^{22}$, while this share drops below $15 \%$ in the US, Germany, the UK and France. This evidence is consistent with a commonly observed feature that children in South-European countries often receive support from their parents at ages - late twenties, early thirties - when other European kids have already become emancipated. In the former countries, family ties may hence play an important role in shaping the individual voting behavior over the welfare state policies, and in particular over social security, of these adult children still living in their parents' house.

The reasons why some adult children fail to become independent may be due to different factors, such as labour market features - high youth unemployment and uncertainty about future income - housing market characteristics, and credit markets imperfections - inability to borrow against future income (see Becker, Bentolila, Fernandes and Ichino, 2002, Brugiavini, Conde-Ruiz and Galasso, 2003, Fogli, 2000, and Manacorda and Moretti, 2001). Regardless of the reason, however, non-emancipated young individuals, whose parents are net recipients from the welfare state (or, alternatively, enjoy the protection of existing labor market regulations), understand that they benefit from the welfare state, via larger private benefits from their parents ${ }^{23}$.

The crucial insight of this literature is thus that family ties may induce some young voters - those who are not emancipated, and whose parents are welfare state recipients, e.g., retirees - to vote in favor of a generous social security system. Using Italian survey data - Boeri, Borsch-Supan and Tabellini (2000) survey on attitudes toward welfare policies and Bank of Italy SHIW Survey (2000) on economic and household information -

\footnotetext{
${ }^{21}$ See Casamatta, Cremer and Pestieau (1998 and 2000) for an analysis of the effect of redistributive feature on the size of the system.

${ }^{22}$ This proportion comprises very elderly parents living with their middle-aged children as well as grown-up children still living in their parents' house.

${ }^{23}$ As suggested by Brugiavini, Conde-Ruiz and Galasso (2003), the existence of a generous welfare state may, however, come at a cost, such as for instance a loss of competitiveness, which in turns reduces job opportunities among the young. In their voting behavior, young individuals would have to trade-off these opposite effects.
} 
Brugiavini, Conde-Ruiz and Galasso (2003) find that the effects of private withinhousehold transfers on voting intentions in favour of pensions of non-emancipated young individuals is positive and significant.

The voting intentions of the non-emancipated young characterized by Brugiavini et al. (2003) is at odds with the features of our calibrated model, which does not distinguish between emancipated and non-emancipated young. Were we to include this additional element of heterogeneity in the model, the results of our simulations in section 4 (tables 7 and 9) would certainly change. For the case of income heterogeneity described in section 5.1, the median voter would not coincide with median age's voter and a voting coalition between elderly and non-emancipated young would emerge to support the pension system. Would these family ties amplify the impact of aging on the size of the pension system? These family arrangements clearly strengthen the political effect described in section 4.1: an increase in the number of families where the elderly live with their adult children increases the overall support from social security. To the extent that within-family intergenerational arrangements will survive in the next fifty years and that they are more common in the fastest aging countries - such as Italy and Spain - we expect these family ties to amplify the impact of aging in these countries.

\section{Comparative Assessment and Policy Implications}

\subsection{Retirement Age}

Our simulations indicate that some reform measures may indeed be effective in keeping the social security expenditure under control: an increase in the retirement age may mitigate the hike of the social security contribution rate, while increasing the private savings for old age consumption. According to our simulations reported in table 9, in Italy, an increase of the retirement age from 58 to 65 years would reduce the equilibrium tax rate by around ten points - from $47.6 \%$ to $37 \%$ - (almost 12 points in the simulations at table 7) while increasing the generosity of the pension benefits by more than $17 \%$. Similar results apply to France and Germany, where the tax rate would be reduced by around six points with an increase in retirement age from 61 to 65 years. In Spain, the UK and US, the increase in retirement age would be lower - respectively three and two years - and the reduction in the contribution rate would range between $2 \%$ and $3.7 \%$. 
In our political-economic environment, postponing retirement affects the two crucial aspects of the aging process (see section 4.1): the dependency ratio - and hence the profitability of the social security system - and the median voter's age, in relation to the retirement age. In particular, this policy measure counterbalances the aging process, by reducing the ratio of retirees to workers. The corresponding increase in the overall profitability of the system would induce every agent to vote in favor of a larger system. An increase in the retirement age, however, affects the continuation return from the system for each individual. In fact, it increases the number of working years - and thus the remaining contribution period, while reducing the residual life at retirement - and thus the period during which pension benefits are collected (see figure 2). To capture the relative importance of these two effects, in table 12 we report the changes in the dependency ratio and in the remaining contribution and benefit periods, induced by an increase in the retirement age to 65 years. A clear mapping between these two effects and our simulations' results appears: the former effect - on the median voter's age, in relation to the retirement age - dominates. The size of the reduction in the equilibrium social security tax rate induced by an increase in the retirement age is strictly related to the magnitude of the shift that occurs between the contribution and the benefit period. Our simulations suggest that on average an increase of one year of the effective retirement age reduces the equilibrium tax rate by almost one and a half percentage point (between $1 \%$ in the US and $1.625 \%$ in Germany).

Table 12. Effects of an Increase in the Retirement Age

\begin{tabular}{|c|c|c|c|c|}
\hline Country & \multicolumn{2}{|c|}{ Pension Dependency Ratio* } & \multicolumn{2}{c|}{ Years of Contributions/Benefits** } \\
\hline & $\begin{array}{c}\text { Unmodified } \\
\text { Retirement Age }\end{array}$ & $\begin{array}{c}\text { Retirement at Age } \\
65\end{array}$ & $\begin{array}{c}\text { Unmodified } \\
\text { Retirement Age }\end{array}$ & $\begin{array}{c}\text { Retirement at Age } \\
65\end{array}$ \\
\hline France & $61.3 \%$ & $48.1 \%$ & $8 / 19$ & $12 / 15$ \\
\hline Germany & $69.5 \%$ & $51.7 \%$ & $6 / 19$ & $10 / 15$ \\
\hline Italy & $101.3 \%$ & $63.7 \%$ & $1 / 23$ & $8 / 16$ \\
\hline Spain & $78.5 \%$ & $63.5 \%$ & $5 / 18$ & $8 / 15$ \\
\hline United Kingdom & $51.4 \%$ & $44.1 \%$ & $10 / 17$ & $8 / 19$ \\
\hline United States & $41.9 \%$ & $36.6 \%$ & $10 / 17$ & $8 / 19$ \\
\hline $\begin{array}{l}\text { Note: *Ratio of retirees to workers, **Remaining years of contributions and benefits for a male median voter. } \\
\text { Source: Authors' calculations }\end{array}$
\end{tabular}


The analysis in section 4 does not address a crucial point: the assessment of the political feasibility of this policy reform. Will a majority of the voters be willing to accept this measure and therefore to postpone retirement? A recent strand of literature in political economics has examined the motivations behind the introduction and the continuation of provisions that allow for early retirement. Conde-Ruiz and Galasso (2003a and 2003b) suggested that the initial introduction of generous early retirement provisions - often achieved by relaxing existing disability or unemployment insurance schemes - represented the political response to labor market shocks, which affected the employment status of several elderly workers. These individuals were close to (normal) retirement age, but had not yet matured the right to an old-age pension; early retirement schemes provided them with a pension benefit. The crucial element for the political success of these provisions Conde-Ruiz and Galasso (2003a and 2003b) also argue - is in their persistence. At the time of their introduction, young and middle-aged workers were willing to support them thereby creating a voting coalition with the initial early retirees - because they expected to benefit from these early pathways from the labor marker later in their working career. An early exit from the labor market may be particularly appealing to workers' with low wages, because of the generosity of the early retirement pensions and of the low opportunity cost of their time. An increase in the effective retirement age would hence break this implicit intergenerational contract, and would be opposed - according to Conde-Ruiz and Galasso (2003a) - by low-income young and middle-aged workers, i.e., the perspective early retirees, and by actual early retirees.

Few surveys and the analysis of some recent pension reforms seem to suggest that this view is still valid to explain the current political support of these schemes. According to a Euro-barometer survey conducted by Eurostat on the retirement intentions, despite the massive discussion on the need to increase the effective retirement age, the average intended retirement for the fifteen EU countries is 60.3 years - an increase of only one year from the current average retirement age of 59.3 years. Moreover, in those countries - such as Germany in 1992, Italy in 1992, 1995 and 1997, Spain in 1997, and the UK in 1995 where pension systems have been reformed to remove the incentives to retire early, these measures have been introduced with a long phase-in period, in order to allow current 
elderly workers to retire still according to the previous rules ${ }^{24}$. Whether these planned policy measures will be implemented in the future, when the aging process becomes more dramatic, it remains to be seen.

Our simulations at section 4 are carried within this aging context. Although they do not allow an assessment of the political feasibility of postponing retirement, as agents vote on one dimension only - the tax rate - some partial indications may still be inferred by analyzing the monetary cost of early retirement. The idea is the following. An increase in the retirement age induces a trade-off, as the individual's remaining life-time net (noncapital) income, i.e., the net labor income plus pension benefits, typically rises, while the available free-time (leisure) decreases. The generosity of the current early retirement provisions tilts this trade-off in favor of leisure; in fact, a large fraction of individuals - in particular, low-income agents - prefer to retire early. The aging process, however - by reducing the average performance of the social security system - will induce a reduction in the generosity of the early retirement as well. Will the agents still be willing to trade-off more income with less leisure, and hence to postpone retirement? To provide a partial answer, we computed the changes in the remaining life-time net income for different individuals under alternative scenarios. In particular, we concentrate on four representative cohorts - a 20, a 35, a 50 and a 65 years old - and three scenarios ${ }^{25}$ : the year 2000 , the year 2050 with the retirement age at the 2000 level and the corresponding equilibrium tax rate, and the year 2050 with the retirement age at 65 years and the corresponding equilibrium tax rate. As a reference, we concentrate on Germany. In the year 2050, with unmodified retirement age, all cohorts would enjoy a lower net income than their year 2000 counterpart $^{26}$. With an increase in the retirement age - coupled with the induced changes in the equilibrium social security tax rate - these (poorer) individuals would however manage to increase their net income by a magnitude between $8.4 \%$ and $11.1 \%$. Our intuition, pursued also in Conde-Ruiz, Galasso and Profeta (2003), is that, as the generosity of the early retirement system decreases, due to the aging process, the new trade-off between income and leisure may induce individuals to postpone retirement.

\footnotetext{
${ }^{24}$ See D'Amato and Galasso (2002) for a discussion of the political constraints faced by the policy-maker during the Italian reforms of the $90 \mathrm{~s}$.

${ }^{25}$ Notice that these three scenarios correspond to the three lines reported in table 9.

${ }^{26}$ In particular, the net income will drop by around $12 \%$ for the 20 , the 35 and the 50 years old and by almost $20 \%$ for the 65 year old retirees.
} 
A very recent proposal, presented in August 2003, to reform the German social security system seems to support this view. The Rurop Commission elaborated two reform measures, see Borsch-Supon and Wilke (2003): an increase in the effective retirement age and a change in the indexation of the pension benefits. The gradual increase in the retirement age, which aims at postponing both the normal and the early retirement age by two years, will start in 2011 and will only be completed by 2035. The former measure introduces a link in the indexation of the pension benefits to the pension dependency ratio. The novelty of the latter reform measure is to directly embody the effects of aging and of postponing retirement in the pension benefit formula. In particular, aging increases the dependency ratio - and hence decreases the pension benefits, even to current retirees while an increase in the effective retirement age (which should start in 2011) reduces the pension dependency ratio, thereby raising the benefits. This link may hence strengthen the political support for an increase in the effective retirement age, by making its positive effect on the pension benefits more transparent.

\subsection{EC: A Case of Deficit of Democratic Representation}

In recent years, there has been a growing attention among EU institutions on the challenge posed by an aging population to the EU pension systems. The 2001 Laeken European Council launched the so-called "open method of co-ordination on pensions", which features eleven common objectives to be achieved by the country member's social security systems on topic such as social protection and financial sustainability. A year later, each country submitted a National Strategy Report on Pension to detail its individual plan on how to meet these common objectives. These reports were then analyzed by the European Commission in an effort to assess the degree of achievement of these common goals.

Is there any sound economic motive behind this desire for coordination? Aside from the issue related to the portability of pension claims, which may reduce labor mobility across EU countries, one may argue that there is little role for EU coordination. As discussed in section 2, social security systems around Europe - albeit all PAYG - differ in their crucial characteristics, such as size, benefit calculation formulas, eligibility requirements and effective retirement age. These systems also differ in their aim. In the UK and the Netherlands, rather small Beveridgean schemes are designed to reduce poverty 
among the elderly, whereas in most other countries, large Bismarckian systems represent a forced saving scheme to ensure old age consumption, in which embodied redistributive elements, such as minimum non-contributory pensions, are often financed through general taxation. Since these differences may indeed reflect different attitudes towards the welfare state or differences in the organization of the society, for instance related to the role of the family, we should expect local government to be in a better position for designing redistributive schemes that best suit each country's needs. Hence, EU coordination may only aim at targeting the systems' financial sustainability, possibly to include the social security implicit debt in the existing "Stability and Growth Pact" criteria on deficit and debt.

There may however be strong political reasons behind this recent interest for a common European policy on pensions ${ }^{27}$. Our simulations in section 4 suggest that the effects of aging on national politics are likely to induce the policy-makers, who are politically accountable towards their aging electorate, to increase the size of the system. Politicians may however face a trade-off. An increase in the social security contribution rate will please the aging electorate, but it may entail a cost. For instance, the politician may have individual preferences in favor of a smaller size of the system. Alternatively, the large size of the system may dampen economic growth and reduce the politician's reelection possibilities. In these scenarios, national governments may be willing to delegate pension policies to the European Commission in order to shift the political cost of a reform decision onto the European institutions. In this case, local governments, acting to meet EU criteria on pension's financial sustainability, could blame the EU for any unpopular reform, and thus bear a lower political cost among the losers from the reform.

The recent European economy history suggests that this delegation of decisions to the EU has proven successful in many instances, such as inflation and exchange rate policy, in order to "tie the (national) government hands".

This shift of political burden to the European Union - in particular to the European Commission - would be facilitated by the deficit of democratic representation enjoyed by the EC. In fact, the Commission needs not be composed by political representatives, such as the members of the European Parliament, and hence is not directly accountable to the 
European voters. This lack of "political accountability" may give the EC enough room to impose some common criteria to reform the EU pension systems, along the suggestions contained in the EC reports on adequate and sustainable pensions. The national government would then be called up to implement these reforms, through specific measures in accordance with the current status of their pension system. On these intergenerational issues, the Commission would thus end up giving voice - and political weight - to those young or yet to be born individuals who today do not vote, but who tomorrow will be asked to foot the bill.

\section{Concluding Remarks}

OECD countries are aging fast. Utmost attention has been given to the financial sustainability of PAYG pension systems, as at their current levels, social security tax rates will not be sufficient to finance the outstanding pension benefits. However, the future of these systems - we argue - depends on political elements. We identify two crucial features of the aging process that affect the political sustainability of pension systems. On one hand, aging tends to increase the proportion of recipients from the system - the retirees - while reducing the proportion of contributors - the workers - and hence decreases the average profitability of the system. As in a portfolio decision, forward looking agents are induced to substitute away from this asset, and thus the size of the system should decrease. On the other hand, an older electorate exerts more political pressure on the policy-makers to obtain larger and more generous systems.

Our simulations provide a quantitative assessment of the effect of aging on the political sustainability of the social security systems in France, Germany, Italy, Spain, the UK and the US. The increased political influence of the elderly voters dominates, as the size of the social security system - chosen by the voters - is forecasted to increase in all countries. Our simulations deliver a strong policy implication. The most effective policy to mitigate this increase in the size of the system is an increase in the effective retirement age. Moreover, we suggest that delegating pension policy to the European Commission may reduce national government's political accountability and facilitate the reforms.

\footnotetext{
${ }^{27}$ In the eve of the EU Presidency of the second semester 2003, the Italian government has argued in favor of introducing pension policies among the topics to be decided at the European level.
} 


\section{Bibliography}

- Aaron, H. (1966) The social insurance paradox. Canadian Journal of Economics and Political Science 32, 371-4.

- Azariadis, C., Galasso, V. (2002). Fiscal Constitutions. Journal of Economic Theory $103,255-281$.

- Becker, S.O., S. Bentolila, A. Fernandes and A. Ichino, Job Insecurity and Children's Emancipation:The Italian Puzzle, mimeo

- Boeri, T. and Börsch-Supan, A. and Tabellini, G. (2002). Pension Reforms and the Opinions of European Citizens American Economic Review, 92, 396-401.

- Boldrin, M. and Rustichini, A. (2000). Political equilibria with social security. Review of Economic Dynamics 3, 41-78.

- Börsch-Supan, A. and C. Wilke (2003). The German Public Pension System: How it Was, How it Will Be. Mea Discussion Paper 34-2003.

- Brondal , S. and Scarpetta, S. (1998). The Retirement Decision in OECD Countries, OECD Working Paper AWP 1.4.

- Browning, E. (1975). Why the social insurance budget is too large in a democracy. Economic Inquiry 13, 373-88.

- Brugiavini, A., J.I, Conde-Ruiz and V. Galasso (2003). Social Security, Private Transfers and Voting Behaviour: the Italian case, mimeo.

- Casamatta, G. and Cremer, H. and Pestieau, P. (2000). The Political Economy of Social Security, Scandinavian Journal of Economics 102(3), 503-522.

- Casamatta, G. and Cremer, H. and Pestieau, P. (2000). Political Sustainability and the Design of Social Insurance, Journal of Public Economics 75 (3), 315-340.

- Conde-Ruiz J.I. and V. Galasso, (2003a). Early Retirement, Review of Economic Dynamics, 6, 12-36.

- Conde-Ruiz J.I. and V. Galasso, (2003b). The Macroeconomics of Early Retirement, CEPR Discussion Paper N. 3896

- Conde-Ruiz J.I., V. Galasso, and Profeta, P. (2003) Economic Development, Aging and Retirement Decisions, mimeo. 
- Conde Ruiz, I. and Profeta, P. (2002). What Social Security: Beveridgean or Bismarckian? W.P. Universitat Pompeu Fabra.

- Cooley, T.F. and Prescott, E.C. (1995). Economic Growth and Business Cycle, in Frontiers of Business Cycle Research, (T.F. Cooley, Ed.), pp. 1 -38, Princeton University Press.

- Cooley T.F., and Soares, J. (1999). Privatizing social security. Review of Economic Dynamics 2, 731-55.

- Costa, D. (1998) The Evolution of Retirement. Chicago: University of Chicago Press.

- Cremer, H. and Pestieau, P. (2003). The double dividend of postponing retirement. International Tax and Public Finance 10, 419-434.

- Cremer, H. and Pestieau, P. (2000). Reforming our pension system: Is it a demographic, financial or political problem? European Economic Review 44, 974-983.

- CSIS and Watson Wyatt (2003). The 2003 Aging Vulnerability Index.

- D'Amato, M. and V. Galasso (2002). Assessing the Political Sustainability of Parametric Social Security Reforms: the Case of Italy. Giornale degli Economisti e Annali di Economia 61, 171-213.

- De la Croix, D and Docquier, F. (2003). Changing Returns to Skill and Experience in France and the US: A general equilibrium approach. Mimeo, CORE Univ. Catholique de Louvain and CADRE, Univ. Lille 2.

- Disney, R. and Johnson, P. ed. (2001). Pension Systems and Retirement Incomes across OECD countries. Edward Elgar editor.

- Epple, D. and Romano, R. (1996) “Ends Against the Middle: Determining Public Service Provision when There are Private Alternatives" Journal of Public Economics 62, 297-325.

- European Commission - Economic Policy Committee (2000) "Progress report to the Ecofin Council on the Impact of ageing populations on public pension systems".

- European Commission Household Panel. Wave 1993, 1994, 1995, 1996.

- Fogli, A. (2000), "Endogenous Market Rigidities and Family Ties”, mimeo, New York University.

- Galasso, V. (1999). The US Social Security: What Does Political Sustainability Imply? Review of Economic Dynamics, 2, 698-730. 
- Galasso, V. (2002). The US Social Security: A Financial Appraisal for the Median Voter. Social Security Bulletin, 64.

- Galasso, V. and Profeta, P. (2002) Political Economy Models of Social Security: A survey. European Journal of Political Economy 18(1), 1-29.

- Gruber, J. and Wise, D. (eds.) (1999). Social Security and Retirement Around the World, University of Chicago Press, Chicago.

- Hansson, I., Stuart, C. (1989). Social security as trade among living generations. American Economic Review 79, 549-59.

- Latulippe, D. (1996) "Effective Retirement Age and Duration of Retirement in the Industrial Countries between 1950 and 1990", ILO Issues in Social Protection discussion paper No.2.

- Manacorda M. and E. Moretti (2002), Intergenerational Transfers and Household Structure, Why do Most Italian Youths Live with Their Parents?, (2002), mimeo, LSE, London.

- Mulligan, C.B., Sala-i-Martin, X. (1999). Gerontocracy, retirement and social security. NBER working paper \#7117.

- OECD (2002). Policies for an Aging Society: Recent Measures and Areas for Further Reforms. Working Paper No.1 on Macroeconomic and Structural Policy Analysis

- Peracchi, F., and N. Rossi, "Nonostante tutto è una Riforma", in Nuove Frontiere della Politica Economica, Il Sole 24 Ore Libri, 1996.

- U.S. Social Security Administration. (1999). Social Security Throughout the World.

- Sjoblom, K. (1985) Voting for social security. Public Choice 45, 225-240.

- Tabellini, G. (2000) A positive theory of social security. Scandinavian Journal of Economics 102, 523-545. 


\section{Appendix A}

This appendix provides some technical details of the politico-economic model, which characterizes the economic and political choices of the agents, in their double role of consumers and voters. We describe the utility function and the agents' budget constraints, the production function and the equilibrium conditions in the factor markets.

Preference Agents' preferences over lifetime consumption - in the first version of the model (see section 4.2) - and leisure (see section 4.3) are described in the following expected utility function:

$$
\begin{array}{r}
\sum_{j=0}^{G} \beta^{j}\left[\prod_{i=0}^{j} \pi_{t, i}^{q}\right] U\left(c_{t+j}^{t, q}\right) \quad \\
\forall j=0, \ldots ., G \\
\forall q=1, \ldots ., Q
\end{array}
$$

where $c$ is consumption and $\beta$ the individual discount rate. The time index is $t, j$ relates to age and $q$ to the education class, $\pi_{t, i}^{q}$ is the probability that a type- $q$ individual of age $i$ at time $t$ survives until the next period and reaches age $i+1$. In section 4 , we do not differentiate by education group, $q=1$, while different education groups are introduced to deal with intragenerational redistribution in section 5 , where $q=3$.

Agents are assumed to exhibit a constant degree of risk aversion. In the model with exogenous labor supply, the utility function is:

$$
U\left(c_{t+j}^{t, q}\right)=\frac{\left(c_{t+j}^{t, q}\right)^{1-\rho}-1}{1-\rho}
$$

where $\rho$ indicates the coefficient of relative risk aversion, while in the model with endogenous labor supply (whose results are discussed in section 4.3), we have:

$$
U\left(c_{t+j}^{t, q}\right)=\frac{\left[\left(c_{t+j}^{t, q}\right)^{\alpha}\left(l_{t+j}^{t, q}\right)^{1-\alpha}\right]^{1-\rho}-1}{1-\rho}
$$

where $l$ is leisure and $\alpha$ represents the relative importance of consumption with respect to leisure.

Budget Constraint Every period, the agents face the following budget constraint: 


$$
\begin{array}{cl}
c_{t+j}^{t, q}+a_{t+j+1}^{t, q}=a_{t+j}^{t, q} R_{t+j}+y_{t+j}^{t, q}+H_{t+j}^{t, q} & \forall j=0, \ldots . G \\
& \forall q=1, \ldots, Q .
\end{array}
$$

where $a_{t+j+1}^{t, q}$ represents the end-of-period accumulated wealth, $y_{t+j}^{t, q}$ is the disposable income at time $t+j$, and $R_{t+j}^{t, q}$ the interest factor on private wealth. Individuals born at $t$ with education $q$ who at any time $t+j$ do not survive to the future period leave an involuntary bequest $H_{t+j}^{t, q}=\left(1-\pi_{t+j-1}^{q}\right) a_{t+j}^{t, q} R_{t+j} / \pi_{t+j-1}^{q}$ to all individuals with the same characteristics ${ }^{28}$.

Net disposable income at time $t+j$ for an agent born at $t$ and of the education group $q$ is given by:

$$
\begin{array}{cl}
y_{t+j}^{t, q}=\varepsilon_{t+j, j}^{q} \cdot h_{t+j}^{t, q} \cdot w_{t+j}\left(1-\tau_{t+j}\right) & \forall j=s^{q}, \ldots ., J-1 ; \\
& \forall q=1, \ldots, Q . \\
y_{t+j}^{t, q}=P_{t+j}^{q} & \forall j=J^{q}, \ldots . G ; \\
& \forall q=1, \ldots, Q .
\end{array}
$$

where $w_{t+j}$ indicates wage per efficiency unit in the period $t+j, \varepsilon_{t+j, j}^{q}$ represents a measure of labor efficiency unit for agents of the $j$ generation and education group $q$ in period $t+j$, $s^{q}$ is the initial age at which agents in the education class $q$ begin their working career and $\tau_{t+j}$ and $P_{t+j}^{q}$ represent respectively the contribution rate to social security and the (annuity) pension benefit to be paid to the group $q$ retirees at time $t+j$. Moreover, in the exogenous labor supply model, $h$ represents the number of worked hours, while in the endogenous labor supply specification $h_{t+j}^{t, q}=1-l_{t+j}^{t, q}$ is endogenous.

Technology In the economy, there exists a constant return to scale production function:

$$
Q_{t}=f\left[n_{t} \cdot(1+\lambda)^{t}, k_{t}\right]=b \cdot k_{t}^{\theta} \cdot\left[n_{t} \cdot(1+\lambda)^{t}\right]^{1-\theta}
$$

where $\lambda$ is the growth rate of labor productivity, $n$ is a measure of per capita unit of labor measured in efficiency units, $k$ denotes per capita stock of capital, $b$ denotes total factor productivity index and $\theta$ the factor share to capital.

\footnotetext{
${ }^{28}$ Alternatively, asset holdings may be redistributed among agents of the same cohort in a lump sum fashion. In Galasso (1999), results are virtually identical under these two alternatives.
} 
In the exogenous labor supply model of section 4.2, the labor supply in efficiency units is determined by the share of workers in every age and education level, multiplied by the correspondent human capital coefficient and by the average number of worked hours, this last element being exogenous:

$$
n_{t}=h \sum_{i=1}^{J} \sum_{q=1}^{Q} \varepsilon_{t, i}^{q} \mu_{t, i}^{q}
$$

In the endogenous labor supply model (section 4.3), the average number of worked hours is endogenous, and hence we have:

$$
n_{t}=\sum_{i=1}^{J} \sum_{q=1}^{Q}\left(1-l_{t}^{t-i, q}\right) \varepsilon_{t, i}^{q} \mu_{t, i}^{q}
$$

Aggregate capital stock in the economy is obtained aggregating individual net saving over education classes and generations

$$
k_{t}=\sum_{i=1}^{J} \sum_{q=1}^{Q} \frac{\mu_{t-i}^{q} a_{t}^{t-i, q}}{1+n}
$$

Optimizing conditions for agents and firms and equilibrium conditions in factor markets define the usual relationship between factor prices and employment in terms of hourly wage (1), $w_{t}$, and rate of return on capital (2), $r_{t}$ :

$$
\begin{aligned}
& w_{t}=f_{1}\left\lfloor n_{t} \cdot(1+\lambda)^{t}, k_{t}\right\rfloor \\
& R_{t}=1+r_{t}=f_{2}\left[n_{t} \cdot(1+\lambda)^{t}, k_{t}\right]+1-\delta
\end{aligned}
$$

where $\delta$ is the parameter of the physical depreciation rate in the economy and subscripts denote the partial derivatives with respect to the relevant variable.

Pension Systems All pension systems under analysis are unfunded. At any time $t$, every agent aged $j$ contributes a fraction of her labor income $\tau_{t} w_{t}^{j}$. In each period, total contributions depend on the tax rate $\tau_{t}$ and on the retirement age $J$ :

$$
T_{t}\left(\tau_{t}, J\right)=\tau_{t} \sum_{j=1}^{J} w_{t}^{j} \mu_{t}^{j}
$$

where $\mu_{t}^{j}$ represents the proportion of agents aged $j$.

Under budget balance, the total amount of pensions to be paid to retirees is equal to the aggregate contributions paid by current workers: 


$$
T_{t}\left(\tau_{t}, J\right)=\sum_{j=1}^{J} P_{t}^{j} \mu_{t}^{j}
$$

where $P_{t}^{j}$ is the pension benefit (annuity) paid at time $t$ to retiree aged $j$.

As shown in table 3, countries differ according to the pension indexation. In a system, such as Italy before the reforms or Germany, where pension benefits are indexed to aggregate productivity (real wage) growth, $\lambda$, we have $P_{t+i, J}=P_{t, J}\left(1+\lambda_{t}\right)$. Whereas if pension benefits are only indexed to inflation, we have $P_{t+i, J}=P_{t, J}$.

Pensions in Italy and the UK In the above formulation, individuals only differ by age. They all retire at the same time and receive the same pension. In section 5 , however, we also consider the intragenerational redistributive effects of the recent reforms in Italy and the UK. Since individuals differ by age and education, we need to fully characterize the pension benefit formulas.

Italy: Pre and post reform regimes differ in the computational criteria, in the retirement age and in the pension indexation (see table 4). In the system prevailing before the Amato reform, pension benefits were computed as the product between the average wage in the last 5 years before retirement $\bar{w}_{J_{q}}^{q}$, the number of years of contributions to the system, $v_{J_{q}}^{q}$, and a coefficient, $\alpha$, which translated the number of contributions years into a replacement ratio:

$$
P_{t, J_{q}}^{q}=\alpha v_{t, J_{q}}^{q} \bar{w}_{J_{q}}^{q}
$$

where $q$ is the agent's education level and $J_{q}$ her retirement age. Pension benefits were indexed to aggregate productivity (real wage) growth.

After the Dini reform, pension benefits are computed according to a defined contribution system $^{29}$. The agent's contributions to the system, that represent a constant fraction of the labor income, are capitalized at an annual rate, $g$, and - at retirement age - are transformed into an annuity according to a conversion coefficient, $\gamma$, which depends on the residual life expectancy at retirement and on the actual retirement age:

\footnotetext{
${ }^{29}$ Notice that the system remains unfunded and contributions are only figurative.
} 


$$
P_{t, J_{q}}^{q}=\gamma \sum_{i=s^{q}}^{J^{q}-1}(1+g)^{J_{q}-i} w_{t-J^{q}-i}^{q, i} \tau_{t-J^{q}-i}
$$

where $s^{q}$ is the initial period in the working career of an agent of education $q$. Moreover, after the Amato reform, pension benefits are only indexed to inflation.

It is important to notice that in our politico-economic model, voters determine the pension tax rate, $\tau$, and, because of the budget balance, the conversion coefficients: $\alpha$, in the pre reforms system, and $\gamma$, after the Dini reform.

UK: The Welfare Reform and Pension Act replaced the SERPS with a new program (S2P), while leaving the Basic State Pension (BSP) untouched. The pension benefits for these three programs are calculated as follows. For the BSP:

$$
P_{B}^{q, t}=\left(\widetilde{w}_{t} N_{q}\right) / 44
$$

where $\widetilde{w}_{t}$ is a threshold (the lower earning limit, LEL) and $N_{q}$ is the number of years of contributions of a type- $q$ retiree at time $t$ (i.e., the number of years during which the earnings were above the secondary threshold, ST). For the SERPS benefit, we have:

$$
P_{S}^{q, t}=\alpha\left(\sum_{i=s^{q}}^{J^{q-1}}\left(w_{t-J^{q}-i}^{q, i}-\widetilde{w}_{t-J^{q}-i}\right)\right) / N_{q}
$$

where $\alpha$ is a conversion coefficient equal to $25 \%$ and $w_{t-J^{q}-i}^{q, i}$ is between the lower (LEL) and the upper earning limit (UEL). For the S2P, the benefits are calculated as follows:

$$
P_{P}^{q, t}=\gamma\left(\sum_{i=s^{q}}^{J^{q-1}}\left(w_{t-J^{q}-i}^{q, i}-\widetilde{w}_{t-J^{q}-i}\right)\right) / N_{q}
$$

where $\gamma=\left\{\begin{array}{lll}40 \% & \text { for } & w_{t-J^{q}-i}^{q, i} \in[L E L, L E T] \\ 10 \% & \text { for } & w_{t-J^{q}-i}^{q, i} \in[L E T, S E T] \\ 20 \% & \text { for } & w_{t-J^{q}-i}^{q, i} \in[S E T, U E T]\end{array}\right.$

Finally, recall that individuals who "contract out" have their contribution rates reduced, however, they do not receive any SERPS or S2P benefits. 


\section{Appendix B}

This appendix describes the sources of the demographic, economic and political data used throughout the paper, as well as the source of information on the structure and the reforms of the social security systems.

Demographics The actual and forecasted life expectancy at birth for all countries, as reported at table 1, are taken from OECD (2002), "Health Data" and from EC - Economic Policy Committee (2000). The actual and the forecasted structure of the population by age - from which we obtain the percentage of elderly in the population in figure 1 and the old age dependency ratio in table 2 - have been obtained from the Eurostat Datashop (Population projections version v.1999 DE base) for the European countries and on-line from the US Census Bureau for the US. For the European countries, the 2050 expected old age dependency ratio are taken from the EC - Economic Policy Committee (2000). The latest survival probabilities by age have been obtained from the national statistical institute in all countries but France, where we use the Sully and Lederman's tables. The US Census Bureau for the US and the Sully and Lederman's tables for France provide also projections on survival probabilities by age for the year 2050. For all other countries, we use the methodology described in the calibration box.

Labor Market For the European countries, the average employment rate by age is calculated using European Commission Household Panel (ECHP) data, while for the US, we use the Bureau of Labor Statistics "Employment and Earnings". Analogously, the wage rates by age - needed to construct the labor efficiency unit profile by age - are obtained from ECHP data for the European countries, and from US Census Bureau "Current Population Report" for the US. The working history by education, used in the simulations at section 5.1, are calculated from ECHP for the UK and from the Bank of Italy Household Panel for Italy. Information on male retirement age in the $90 \mathrm{~s}$ and in the $50 \mathrm{~s}$ are taken from ILO data (Latulippe, 1996). Data on effective retirement age for the year 2000 are obtained from ECHP data for France, from the Bank of Italy Household Panel for Italy (for 1992), 
from ECOFIN reports for Germany and the UK, and from Gruber and Wise (1999) for the US and Spain $^{30}$.

Political and Economic data In the calculation of the median age among voters, we include the election's turnout rates by age. These are taken from IDEA (1999) "Young Voters Participation" for European countries and from US Census Bureau "Reported Voting and Registration" for the US. Regarding economic data, values of the average capital share are taken from national accounts. The long term characteristics of each economy, as characterized by the capital-output ratio are taken from several sources: for France, Germany, the UK and the US from Maddison (1995) ("Monitoring the world", $O E C D$ ); for Italy, D’Amato and Galasso (2002); and for Spain, Puch and Licandro (1997) (Investigaciones Economicas, 21, 361-394). Also the exogenous productivity growths, which are measured by the average per-capita GDP growth rate, are taken from different sources: the EC - Economic Policy Committee (2000) for the 1990s average value for France, Germany and the UK; D’Amato and Galasso (2002) for Italy; national accounts for Spain and Galasso (1999) for the US. In the simulations, we use the projections for the year 2050 in the EC - Economic Policy Committee (2000), while we keep the 1990s average value for the US.

Pension Systems Most of the information on the pension systems of the European countries are obtained from local sources, from the SSA publication "Social Security Throughout the World" and from EC - Economic Policy Committee (2000); information on the US social security system can be obtained online from the US SSA website. Information on pension reforms are taken mainly from the EC - DG Employment and Social Affairs (2002) "Social Protection in Europe 2001", from Economic Policy Committee (2002) "Reform Challenges Facing Public Pension System” and from a Rodolfo De Benedetti report (2000) "Monitoring Slow Pension Reforms in Europe".

\footnotetext{
${ }^{30}$ In particular, from Boldrin, Jiménez-Martín, and Peracchi, "Social Security and Retirement in Spain" in Gruber and Wise (1999).
} 


\section{RECENT WORKING PAPERS FROM THE \\ Center For Retirement Research at Boston College}

Living Arrangements and Supplemental Security Income Receipt Among the Aged Melissa M. Favreault and Douglas A. Wolf, February 2004

Interactions Between Social Security Reform and the Supplemental Security Income Program for the Aged

Paul S. Davies and Melissa M. Favreault, February 2004

Supply-Side Consequences of Social Security Reform: Impacts on Saving and Employment

Barry Bosworth and Gary Burtless, January 2004

It's All Relative: Understanding the Retirement Prospects of Baby-Boomers

Barbara A. Butrica, Howard M. Iams, and Karen E. Smith, November 2003

The Notional Defined Contribution Model: An Assessment of the Strengths and Limitations of a New Approach to the Provision of Old Age Security

John B. Williamson and Matthew Williams, October 2003

Simulating the Distributional Consequences of Personal Accounts: Sensitivity to Annuitization Options

Cori E. Uccello, Melissa M. Favreault, Karen E. Smith, and Lawrence H. Thompson, October 2003

Aggregate Implications of Defined Benefit and Defined Contribution Systems Francisco Gomes and Alexander Michaelides, September 2003

Can Unexpected Retirement Explain the Retirement-Consumption Puzzle? Evidence for Subjective Retirement Explanations Melvin Stephens Jr. and Steven J. Haider, August 2003

Employment, Social Security and Future Retirement Outcomes for Single Mothers Richard W. Johnson, Melissa M. Favreault, and Joshua H. Goldwyn, July 2003

The Outlook for Pension Contributions and Profits in the U.S. Alicia H. Munnell and Mauricio Soto, June 2003

Social Security Reform and the Exchange of Bequests for Elder Care Meta Brown, June 2003

All working papers are available on the Center for Retirement Research website (http://www.bc.edu/crr) and can be requested by e-mail (crr@bc.edu) or phone (617-552-1762). 